\title{
A Fisiografia \\ e sua Paisagem \\ Na Busca da Personalidade do Lugar
}

\section{Eduardo Yázigi}

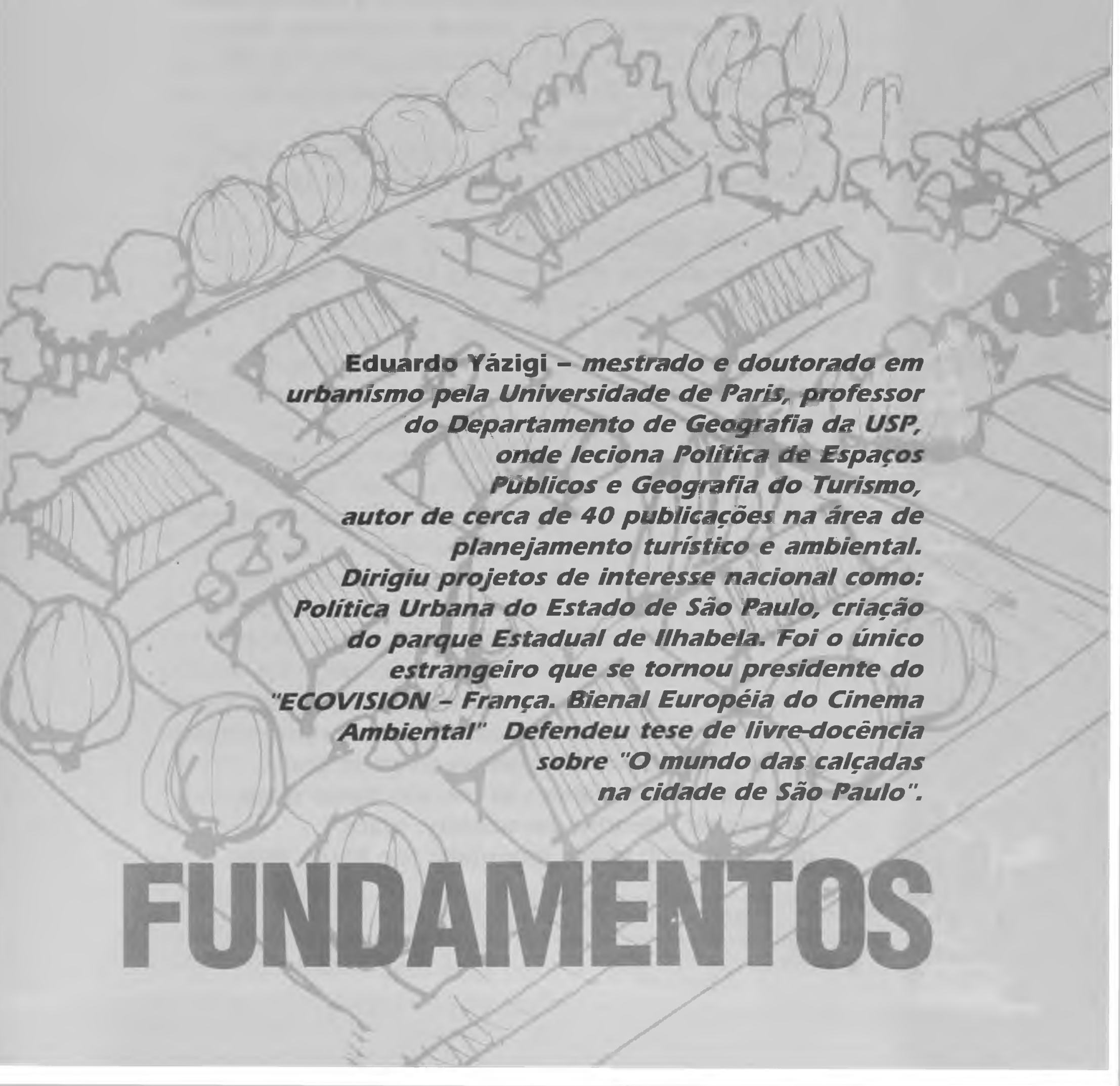


A presente preocupação consiste em considerar a fisiografia como o melhor meio de conservação de identidades locais. De fato, atualmente, verificamos fortes características que comprometem os traços locais: a mobilidade do trabalho (e daí alguma miscigenação); técnicas e novos materiais de construção; informações que produzem novos padrões culturais, etc. Nessas condições, a vida cotidiana e, conseqüentemente, o turismo, tornam-se menos genuinos. Neste caso, os aspectos físicos da geografia podem ser os mais fortes vetores na preservação da paisagem. Do mesmo modo, o respeito à ordem natural pode gerar soluções únicas, naquele sentido de que uma casa de campo na floresta tropical não é a mesma coisa que sua congênere nas estepes ucranianas. Meu artigo representa uma exploração preliminar das personalidades do litoral e das montanhas no estado de São Paulo.

Palavras-chave: identidade, personalidade, lugar, fisiografia, litoral, montanha, estado de São Paulo.

Here, the main idea concerns to support physiography as the best way to keep locals identities. In fact, actually we verify strong features that are removing traditionals characteristics: mobilities for working land so some ethnical mixture); modern techniques and new material on building; information producing new patterns through television, etc. Under these conditions, the day life and consequently the tourism subject become less genuine. In this case, physical aspects of geography could be the strongest vectors to preserve landscape, because they are relatively stable. Also, respect to natural order can create a unique solution on land use, in the sense that a cottage on the rain forest is not a cottage on ucranian steppes. This attitude too represents a new cutural and policital feature. My article represents a preliminary exploration between coast and mountains personalities in the São Paulo state. Key words: identify; personality; place; physiography; coast; mountais; Sao Paulo state. 


\section{A Fisiografia \\ e sua Paisagem \\ Na Busca da Personalidade do Lugar}

1 ntrodução: a estetização da miséria

Considero muito preocupante a situaçāo da paisagem no Brasil e acho inconseqüentes os interlocutores que revidam dizendo que em outros lugares também está ruim. Nem quatro séculos de exploração agrária mercantilista (ou simplesmente colonial) conseguiram provocar uma destruição equiparável a dos últimos 50 anos. De resto, aliás, há de se convir que no meio urbano, pelo menos, quase tudo o que o Brasil produziu de melhor recai nas expressões do barroco e do neoclassismo e, o que é mais irônico, nem sempre contando com profissionais da arquitetura ou do paisagismo, salvo casos excepcionais. Tal foi o caso da Missão Francesa do século 19 ou dos engenheiros e arquitetos dos tempos áureos do café/cacau/borracha - com significado restrito a alguns lugares muito específicos. O mais substancial da paisagem não era assinado. É só com Burle Marx que se inaugura nova fase. No mais, não será necessário recontar os pormenores do vandalismo generalizado contra o patrimônio ambiental (natural e cultural). Isto já é lugar comum entre os que estudam a matéria. Se em meio século (isto é, um átimo na escala da história) se foi capaz de tanto, imagine-se o que nos espera em direção ao futuro, agora que os meios de intervenção são mais poderosos e a arbitrariedade maior.

Há um modo de pensar comum entre os fazedores de consciência maniqueísta, e por isso extremamente nocivo, segundo o qual a preocupação com os aspectos formais (a paisagem também o é) dissimularia o aperfeiçoamento da essência das coisas, essa sim, a única válida. Subentendo que se a preocupação com o não-visível prevaleceu, estaríamos vivendo no melhor dos mundos, com habitação, educação e assistência médica de alto nível; sem miséria, 
sem violência e tudo o mais que faz a felicidade da vida cotidiana dos grupos sociais... A este propósito, acho muito oportuno lembrar que, segundo todo pensamento heurístico (Edward de Bonno, Arthur Koestler, W I. Beveridge e um sem-número de psicólogos), isto é, o que elabora as teorias do campo da criação, nada mais incompatível com a criatividade do que o pensamento binário sim-não ou certoerrado. Criação, enquanto solução de um problema qualquer acaba surgindo em meios aos indiziveis tons possíveis entre uma alternativa e outra. Neste caso específico, a busca de uma paisagem melhormente organizada não implica em se descuidar dos problemas sociais, mesmo porque cultura é justamente o conjunto de respostas que o grupo dá aos desafios do meio. Em duas palavras, nada mais suicida do que a mentalidade que explicitamente, ou nas entrelinhas, faz apologia da miséria. Como toda forma tem sua função embutida, a busca da construção da identidade através da paisagem seria mesmo um modo de promoção da cidadania, já que a afirmação dos mais diferentes grupos, num contexto de participação no planejamento, passaria por sua inclusão no sistema, como meio de eliminar a miséria da paisagem.

James Hillman (1993), tanto como crítico de cidade (esteve no Brasil) como psicanalista, explica que "o efeito narcoléptico das discussóes de estética, o moralismo disfarçado de que a beleza é "boa para você", ou que, na verdade, ela é o próprio Bem, fez com que todo um século se virasse contra qualquer coisa relacionada com beleza, clássica ou romântica (p. 128)... As discussóes sobre beleza durante muito tempo, neste século têm sido pervertidas pela apropriação totalitária do tema, tão freqüentemente negligenciado pelas preocupações humanistas $e$ existenciais do desenvolvimento social democrático. A direita política assumiu discussões intocadas pela esquerda. Se não abrirmos amplamente essa questão, ela permanecerá não somente reprimida, mas, pior, sujeita a um mal uso totalitário... Pois, sejamos claros, o fascismo hoje não está onde estava há cinqüenta anos; nem está aqui em nossa disputa desse tema. Hoje, o totalitarismo está na televisão, em sua glorificação do sentimento humano, com uma linguagem uniforme, e no patrimônio de massa agitado pelo derramamento de sangue (p. 129)... Queremos o mundo porque ele é bonito, seus sons, seus cheiros e suas texturas, a presença sensorial do mundo como um corpo. Resumindo, por baixo da crise ecológica está a crise mais

\begin{tabular}{|c|c|c|}
\hline 74 & Paisagem & São Paulo n. 11 p. $71 \quad 98$ dez. 1998 \\
\hline & $\begin{array}{l}\text { Ensaios } \\
11\end{array}$ & \\
\hline
\end{tabular}


profunda do amor: que nosso amor tenha abandonado o mundo, que o mundo esteja desamado, é o resultado direto da repressão da beleza, de sua beleza e de nossa sensibilidade para ela (p.131)"

Em duas palavras, tudo aquilo que já é lugar-comum: a deterioração da paisagem tem seu correspondente no cotidiano dos habitantes e funciona como elemento de repulsa ao turismo ou veraneio; convir com este estado de coisas é propositadamente manter o grau de exigência do brasileiro no nível mais baixo; é obstar sua cidadania pela recusa de fazer firmar sua identidade na perspectiva da ascensão social. Sem inverter essas posições, parece-me mesmo que toda ação voluntária de paisagismo se limitará aos intramuros, cujo know-how o Brasil já está exportando... Tudo isto porque ainda não somos suficientemente capazes de entender e defender a esfera pública. A paisagem é pura esfera pública.

A paisagem urbana brasileira encontra alta representatividade nos subúrbios, mostrados várias vezes, a cada dia, pelas mídias, pois as carências e violências de que são palco alimentam um tipo bem popular de jornalismo. Como se esses males já não fossem suficientes, acrescem-se de outro ainda pior: a familiarização de todos com a miséria e a feiura. $O$ interessante é que andei comparando as rendas familiares de paulistanos de periferia com seus equivalentes atenienses, chegando à conclusão que não são muito díspares, havendo muitos casos em que a renda aqui é superior, especialmente entre os prestadores de serviço. No entanto, embora os subúrbios não costumem ser lá grande coisa, Atenas (de extensos subúrbios pobres) está muito, mas muito longe de exibir os quadros da urbanização brasileira: os esgotos a céu aberto; as construções em carne viva, isto é, sem qualquer acabamento; os "puxados" para todos lados possíveis, impedindo qualquer harmonia no conjunto; a mistura de materiais, a ausência de árvores ou até de vasos com flores; as soluções técnicas incompreensíveis; os refugos materiais de toda espécie... Não será isso, grandemente, expressão de uma cultura? Não será possível ser pobre com um pouco mais de dignidade, pelo menos para tornar mais amena a vida em comunidades de vizinhança? Esta mesma paisagem suburbana, típica de grandes cidades, já se faz presente em meio aos melhores sítios turísticos. 


\section{J ma questão de vontade politica}

Enquanto muitos países estão em discussões filosóficas sobre o pósmodernismo, nossa esfera não consegue ao menos deter as arbitrariedades na paisagem e no espaço público. Intervenções aberrantes, adiantemos, que sequer estão vinculadas à dita voracidade do capital. A este se soma a permissividade geral, aquele temor de que é preferível fazer vistas grossas a receber outro ataque como resposta. De resto assinalo ainda: a) a incompetência administrativa das municipalidades e do Estado, tanto nos projetos próprios como no estabelecimento de normas (fotos 1 a 3); b) a apropriação indevida do espaço público (veja-se em direito urbanístico como se define o espaço públicol, tanto por razões pessoais como pela avidez sem limites do capital (fotos 4 e 5); c) o "gosto" já denunciado por todas as partes, segundo o qual não é mais possível entupir o espaço público com equipamentos (foto 6); d) a visão limitada do planejamento regional, incapaz de prever usos e ocupações do solo em função da preservação, principalmente do parcelamento incontido da terra. Sob este último aspecto, aliás, é preciso acrescentar que sendo o excessivo parcelamento incompatível com a preservação, só restaria a alternativa, sempre ignorada, de se prover a sociedade com arquitetura social para a habitação e o lazer, em distribuições equilibradas de zonas de alta, média e baixa densidades, em função da proteção da paisagem circundante. Isto

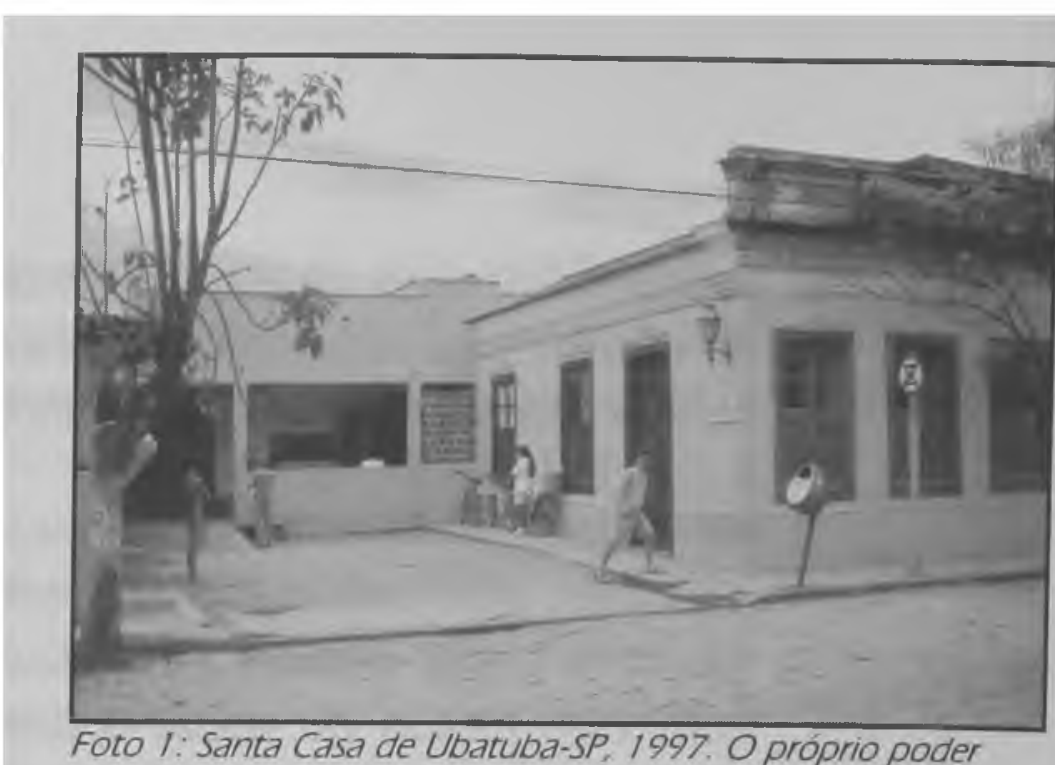

Foto I: Santa Casa de Ubatuba-SP. 1997. O próprio poder público contribui à descaracterização do pouco que restou de tempos passados, promovendo reformas sem critérios específicos

Fotos: Eduardo Yázigi

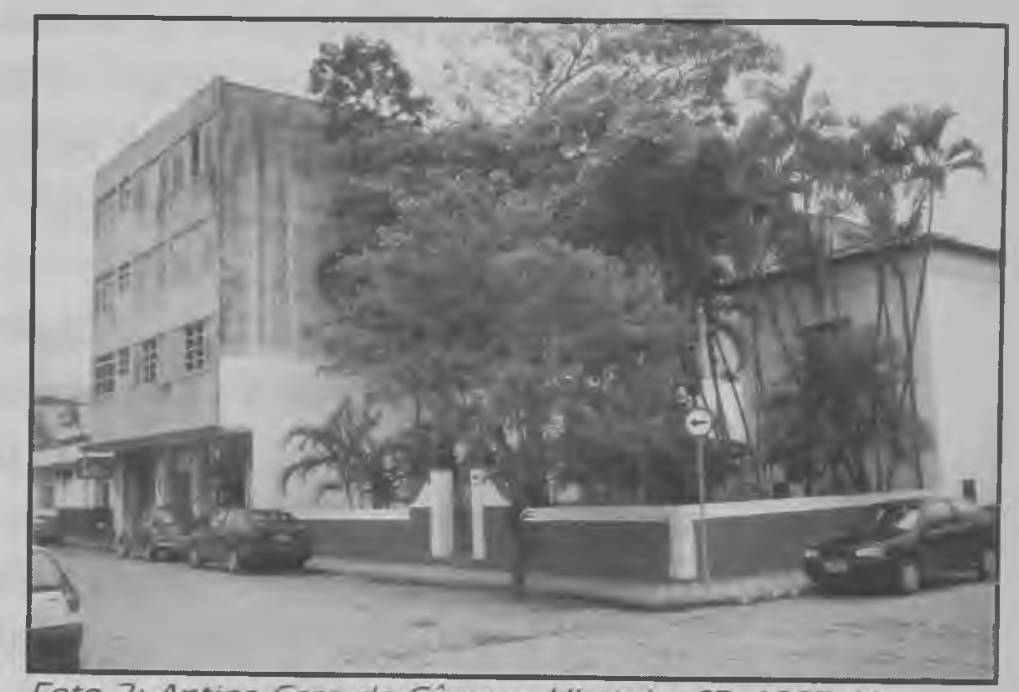

Foto 2: Antiga Casa da Câmara, Ubatuba-SP, 1997. Um edifício de apartamentos construido ao lado do monumento histórico, mostra a permissividade da ausência de normas Fotos: Eduardo Yázigi

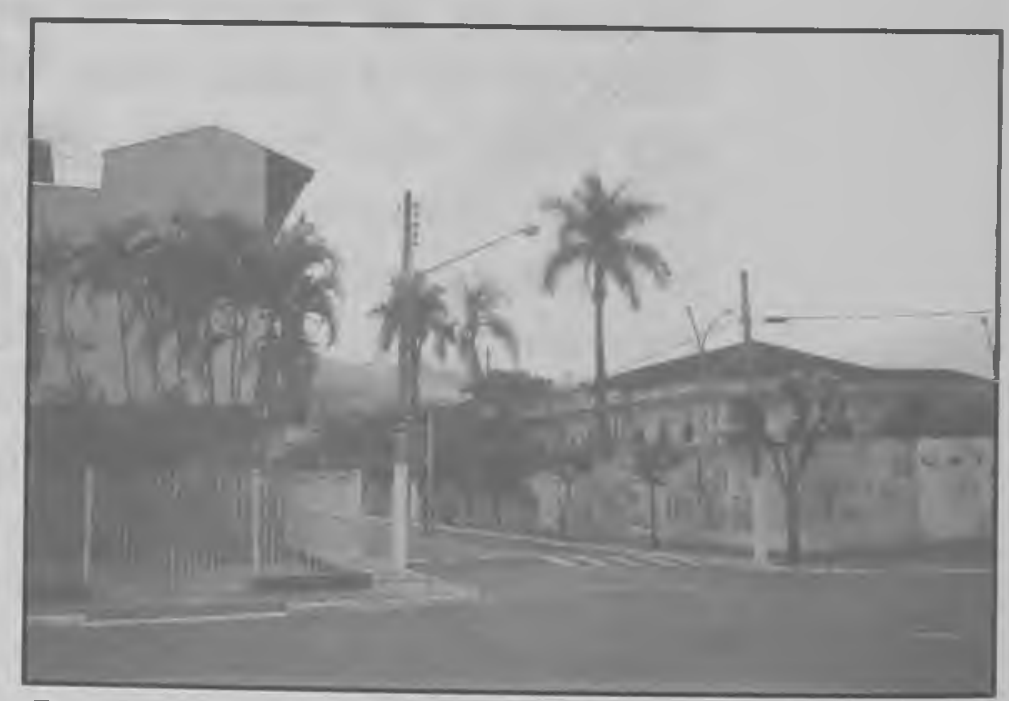

Foto 3: Grupo Escolar de São Bento do Sapucaí-SP, 1997: apesar da expansão do turismo, a municipalidade permitiu a construção do único édifício da cidade, de forma a prejudicar a zona de ambiência. No mais tenta imitar Campos do Jordáo

Fotos: Eduardo Yázigi

\begin{tabular}{|l|l|}
\hline 76 & $\begin{array}{l}\text { Paisagem } \\
\text { Amblente } \\
\text { Ensalos } \\
11\end{array}$ \\
\hline
\end{tabular}

São Paulo n. 11 p. 7198 - dez. 1998 

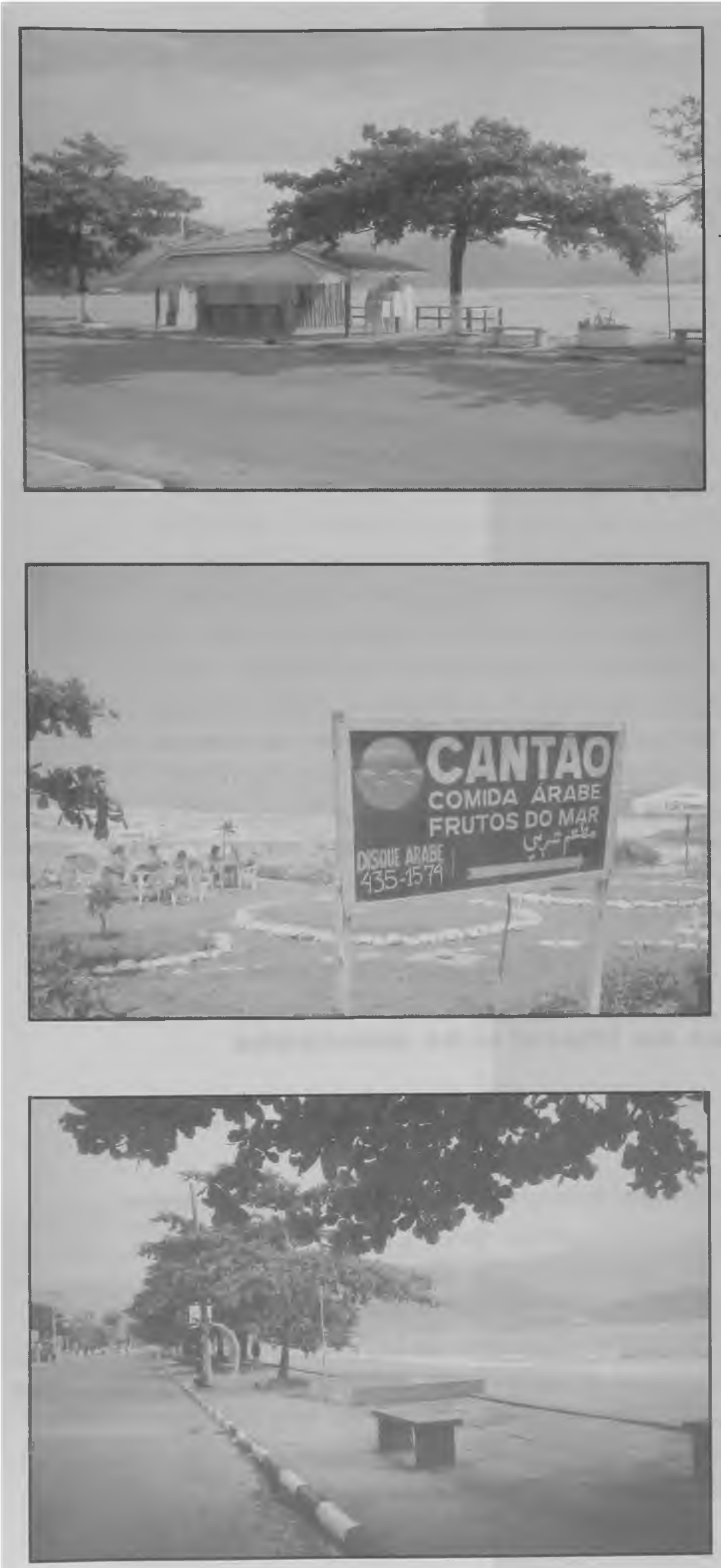

Foto 4: Praia do Itaguá,

Ubatuba-SP, 1997. Com total apoio da prefeitura, quiosques comerciais se espalham a intervalos minimos de distância nas praias Grande, do Itaguiá... O senviço de apoio ao banhista não justifica tal quantidade de bares. Do ponto de vista deste estudo. os quiosques comprometem os visuais das paisagens naturais, a partir do principal ponto de percepção, a calçada beira-mar Fotos: Eduardo Yázigi

Foto 5: Praia Grande, UbatubaSP, 1997. Placas comerciais são colocadas ao arbítrio do proprietário do estabelecimento comercial. Note-se a distância conjuntural da legenda em árabe, dos tempos em que só havia cultura caiçara. São os novos rumos da identidade Fotos: Eduardo rázigi

Foto 6: Praia do Itaguá, Ubatuba-SP, 1997. O entupimento do espaço público com equipamentos que náo se justificam de nenhum ponto de vista vem se constituindo numa característica das administraçôes públicas brasıleiras. Neste caso agrava-se não só com o comprometimento de percepção dos visuais, como do próprio uso da calçada, por exemplo. inviável para alguém que porta um carrinho de bebê ou para um idoso. $A$ "alegação" teria sido buscar impedir que autos estacionassem no passeio. Ou seja, a calçada não serve nem o pedestre nem o carro. Para que existir entáo? ... Onde fica o aperfeiçoamento jurídico? O espaço sempre contém história, mas a manutenção do status quo indica conivência das administrações

Fotos: Eduardo Yázigi

\section{Paisagem Ambiente Ensaios


nos remeteria a outro item e) todas zonas de baixa densidade teriam de ser severamente taxadas.

No Brasil há uma predisposição de não aceitação das leis, especialmente quando se pertence a segmentos mais elevados, pois sujeitar-se a ela seria uma forma de falta de poder... Já foi mais do que explicado pelos antropólogos. Diz-se, a saída é negociar... Mas perdese de vista que negociação sem base jurídica só faz a corda arrebentar do lado do mais fraco; esquece-se, também, que nos casos de golpes de Estado, a regra primeira consiste justamente em fechar o legislativo... Como se olvidou depressa que a maior questão social dos anos 80 foi justamente a briga pela Constituinte! Sim, nāo há como planejar sem ter leis e normas como referências, embora ninguém mais seja tão ingênuo a ponto de julgar que isto baste. Negociação sim, também, mas com amplos segmentos - o capital social ou ONGs em geral - atuando energicamente. No mais vale ainda comentar que, bem ou mal, muitas categorias de leis têm sido eficazes: os direitos da mulher nos bens do marido; os direitos de empregados; os direitos do consumidor; boa parte da ação preservacionista do Ibama e, em muitos casos, não se pode negar que as leis de zoneamento têm sido mais ou menos seguidas. Descuidar-se dos aspectos jurídicos significa, precisamente, desimpedir o caminho, como o banditismo quer. O aperfeiçoamento do sistema legal é uma conquista plena da cidadania, que em poucos anos de redemocratização tem procurado avançar contra movimentos seculares de sociedade senhorial.

\section{$\exists$ studo de casos no litoral e na montanha}

Este artigo representa apenas um esforço inicial de reflexão, de uma ampla pesquisa que estou conduzindo pelo CNPq, referente à personalidade do lugar no planejamento territorial. Elegi uma apreciação do litoral norte do estado de São Paulo (llhabela, São Sebastião, Caraguatatuba e Ubatuba) e da Serra da Mantiqueira (Águas de Lindóia, São Bento do Sapucaí e Campos do Jordāol, analisando praia e montanha. Parti da constatação que a grosso modo "está ficando tudo com a mesma cara" (fotos 7 e 8), tanto devido a fatores históricos deste século, como aos efeitos da globalização.

\begin{tabular}{|c|c|c|}
\hline 78 & Paisagem & São Paulo n. 11 p. 7198 dez. 1998 \\
\hline & $\begin{array}{l}\text { Ensaios } \\
11\end{array}$ & \\
\hline
\end{tabular}




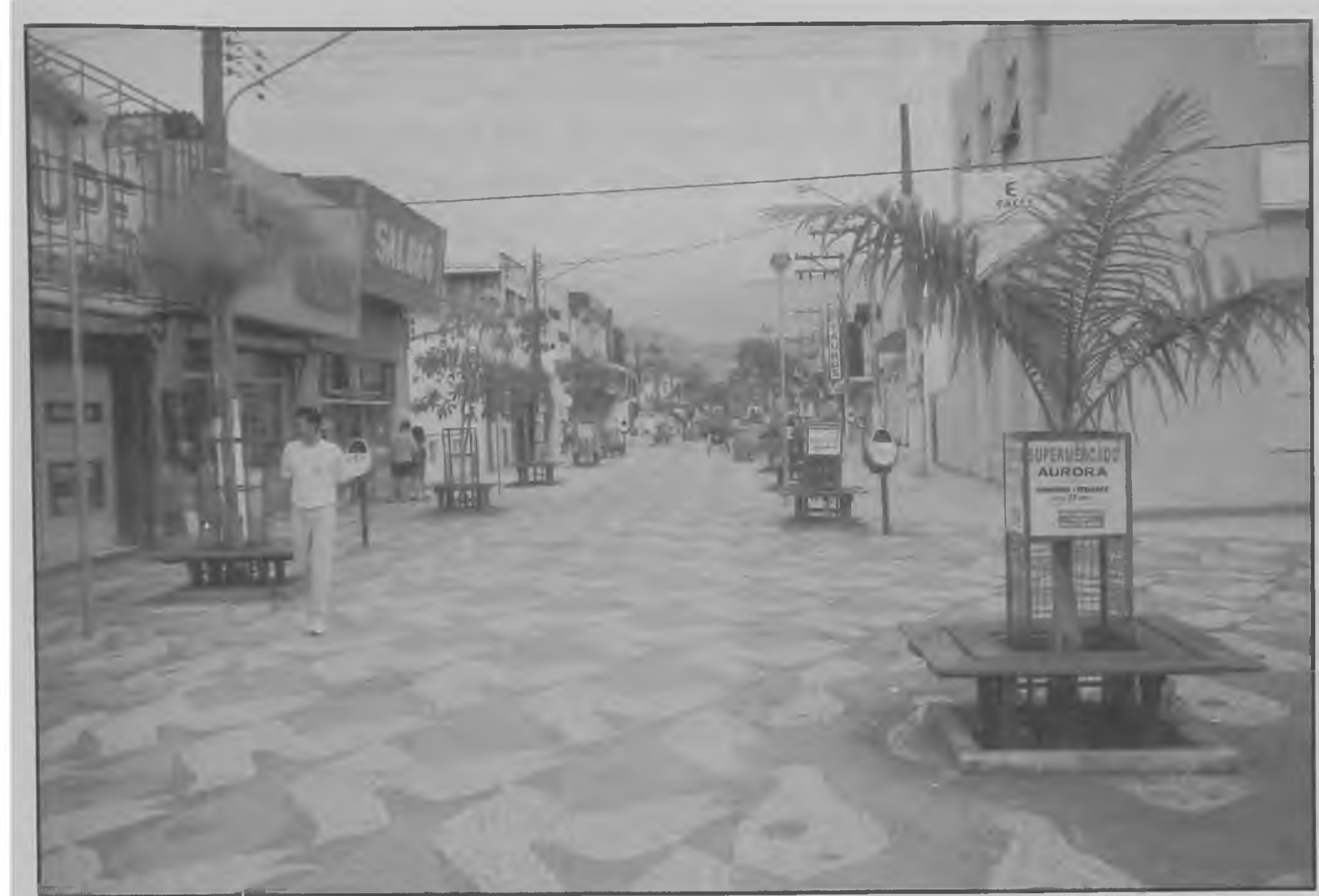

Foto 7: Calçadão do certro de Ubatuba-SP, 1997. O instinto de copias fáceis, sem criatividade, leva à mesmice dos lugares, com soluçōes que tanto faz serem do extremo norte ou do extremo sul do país. Decidiu-se que todo e qualquer lugar tem de ter rua de pedestre e pronto! Não se tem em conta a regulamentação da publicidade, as percepçōes do meio natural e muito menos um projeto original. Calçadóes são típicos do pós-modernismo, mas ubatuba sequer conheceu o modernismo Fotos: Eduardo Yázigi

Foto 8: Estabelecimento bancário, centro de Ubatuba-SP, 1997. Grandes firmas, seus padrōes arquitetônicos e suas marcas visuais se repetem em qualquer lugar, pouco se importando com a

identidade dos mesmos. Uma prática bem diferente daquela praticada há 20 anos pelo então Ministro da Fazenda. Carl Richebieter, por exemplo, que instruía que as agências da Caixa Econômica Federal deveriam prioritariamente instalar-se em edifícios antigos das diferentes cidades, em vista da memória Fotos: Eduardo Yázigi

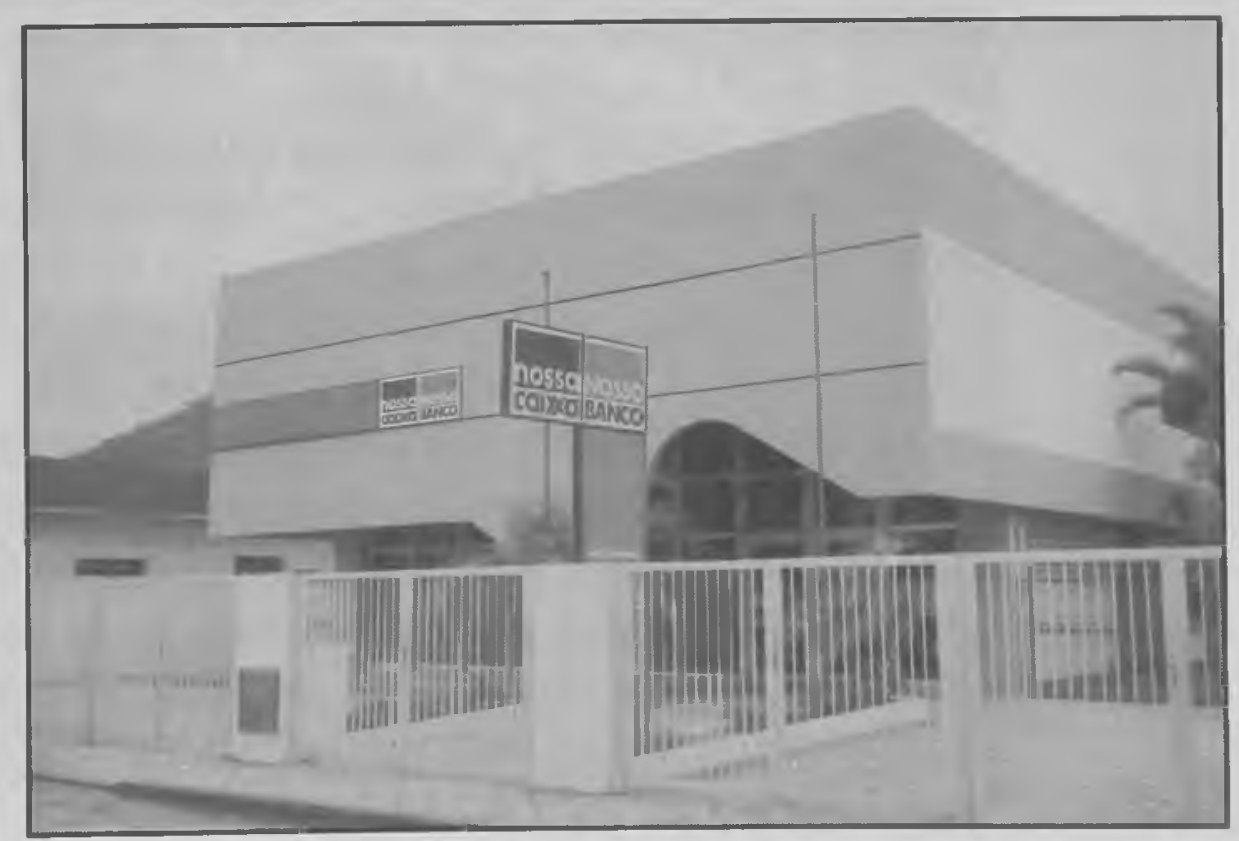


Uma primeira aproximação da abordagem turística mostrou que há rituais de praia e de montanha. A praia, como lugar de sol, convida à mostra do corpo, fato este que faz congregar cada vez mais as jovens galeras, gerando um turismo muito específico ligado aos esportes náuticos; às rodas de música e cerveja em ambientes costumeiramente ruidosos; às paqueras e ambientações noturnas, nas quais as avenidas (e seus símbolos ) assumem lugar tão importante quanto as discotecas - de acesso nem sempre aberto a todos. O próprio emprego do tempo fica sujeito aos imperativos climáticos e à freqüentação da praia. A regra é bronzear-se e abusar da fórmula dos três "S"' sea, sun and sex. Há um clima jovem, próprio de praia. Destas premissas derivam várias representações, até mesmo na decoração das vitrines. O calor próprio do litoral enseja soluções arquitetônicas de ampla ventilação e por isto muito abertas. Há também os idosos que, precisando de lugares quentes e planos, acabam optando pelo litoral. Mas litoral e praia não são exatamente a mesma coisa. Inversamente, a montanha, pela dispersão demográfica que impõe (isto é, não tem a continuidade imposta pela linha do mar) acaba representando mais recolhimento e talvez, assim, mais própria aos maduros e amantes da tranqüilidade.

A quietude seria mais condizente com a montanha. Sua "liturgia" implica na glorificação do frio. Este rito faz apologia da lareira, do vinho, do conhaque e do aconchego. Fondue na refeição, chocolate na sobremesa... Casas de decoração, antiquários, profusão de revistas do gênero à venda. Comércios de roupas de lã, cutelaria e produtos finos em geral. Busca-se qualquer objeto ou rito que lembre a Europa fria. $E$ mais: caminhadas a pé, a cavalo ou passeando cães de raça. Assim se celebra em Campos do Jordão, São Paulo, ou Gramado e Canela, Rio Grande do Sul. E também trilhas, cachoeiras e o silêncio da asa delta, próprias de montanha, ainda que a montanha esteja no litoral. Ora, se o frio, por exemplo, é gerador de todo um tipo de vivência, há de se pensar que a urbanização genérica (por exemplo asfaltando todas vias ou diminuindo a vegetação urbanal acaba esquentando e neutralizando a personalidade do lugar Aliás, lugares como Campos do Jordão construíram sua identidade de tal modo ligada ao frio, que hoje são rejeitados no verão, invertendo o processo das praias... A vida local sai prejudicada, a menos que um trunfo de marketing modifique o imaginário de seus freqüentadores. Tudo isto foi dito porque estes pequenos traços ligados ao turismo vão sendo indistintamente assumidos por um ou outro complexo, por imitação ou porque rendem monetariamente, fazendo com que tudo fique "com a mesma cara" $A$

\begin{tabular}{|c|c|c|}
\hline 80 & Paisagem & São Paulo n. 11 p. 7198 dez. 1998 \\
\hline & $\begin{array}{l}\text { Ensaios } \\
11\end{array}$ & \\
\hline
\end{tabular}


montanha acaba por não seduzir o jovem e, na mesma linha, espanta seus possíveis usuários mais maduros. Ademais há montanhas e montanhas, praias e praias, cada qual com suas identificações que o planejamento, em tábula rasa, não costuma ter em conta. A redução tem criado um padrão alpino, supostamente bom para todos lugares altos, no Piauí ou no estado de São Paulo. A mesmice tende a atingir a vivência, a arquitetura, o urbanismo, o paisagismo.

Assim andam esses núcleos turísticos. O espírito de imitação das administrações e dos empresários (no lugar de projetos genuínos ao lugar) que querem repetir tudo o que "está dando dinheiro" tem levado à despersonalização e à comicidade. Os ricos e bem-nascidos afirmam com facilidade suas identidades, grandemente garantidas pelos mundos emuralhados à la Auschwitz (nova identidade brasileira) e pelos regulamentos de condomínios. Os pobres se contentam com as periferias sórdidas que, quer se queira ou não, também vão formando identidade. No meio destes, o resto, as classes médias de exteriorização ainda não claramente tipificadas, vagando entre os mais diversos rumos. Ao contrário de muitos países, como a França ou Inglaterra por exemplo, que mantêm padrões regionais arquitetônicos e urbanísticos obrigatórios, mais ou menos congelados num estilo do passado, a maioria das localidades brasileiras ainda não definiram seus rumos com personalidade (foto 9). Este seria um dos estigmas dos países de colonização recente e sem vigor de afirmação cultural.

O que não pode ser negado e se expande de modo incrível é o que atrevo-me a denominar alpinização das montanhas (e agora também das praias!). Fixou-se, no vulgo e nas administraçōes, que lugar turístico tem de ser de "estilo alemão" (ou suiço...), conforme citações reais em decretos municipais. Houve casos históricos, já sabemos, que alemães ou eslavos preferiram fixar-se em montanhas, com seus modelos arquitetônicos, por ocasião de suas primeiras migraçōes. Essa descoberta por brasileiros, já antiga, diferenciou-os da então pouca variedade arquitetônica brasileira. Ora, como alguns dos primeiros movimentos turísticos do Brasil se depararam com o "estilo alemão" ficou como herança, no imaginário do brasileiro, que toda montanha tem de ser alemã... Tenho visto estímulos a esse pseudo-estilo nas regiōes Sul, Sudeste e nos estados do Rio de Janeiro e Espírito Santo. Busca-se uma "arquitetura alemã" mas a de antigamente, não a de hoje... Falo em pseudo-estilo porque jamais existiu um estilo alemão ou comida alemã, até mesmo na Alemanha! Lá, percebem-se isso sim,

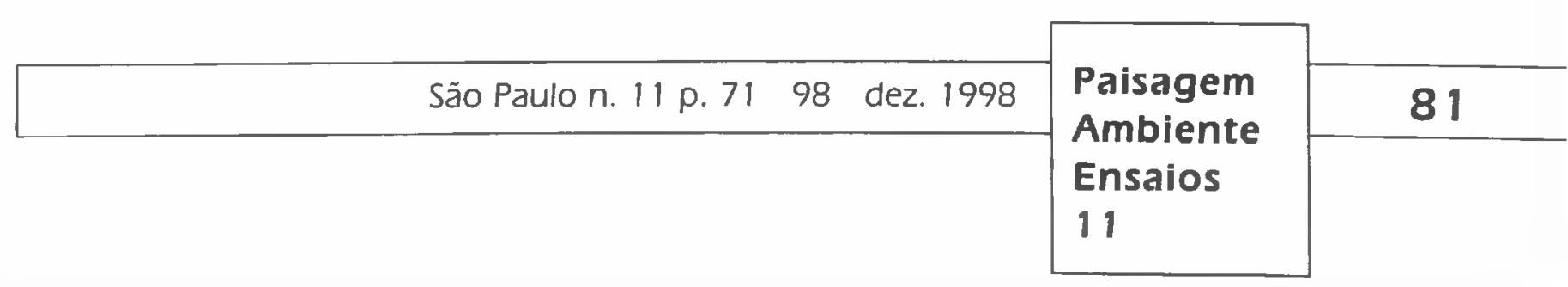




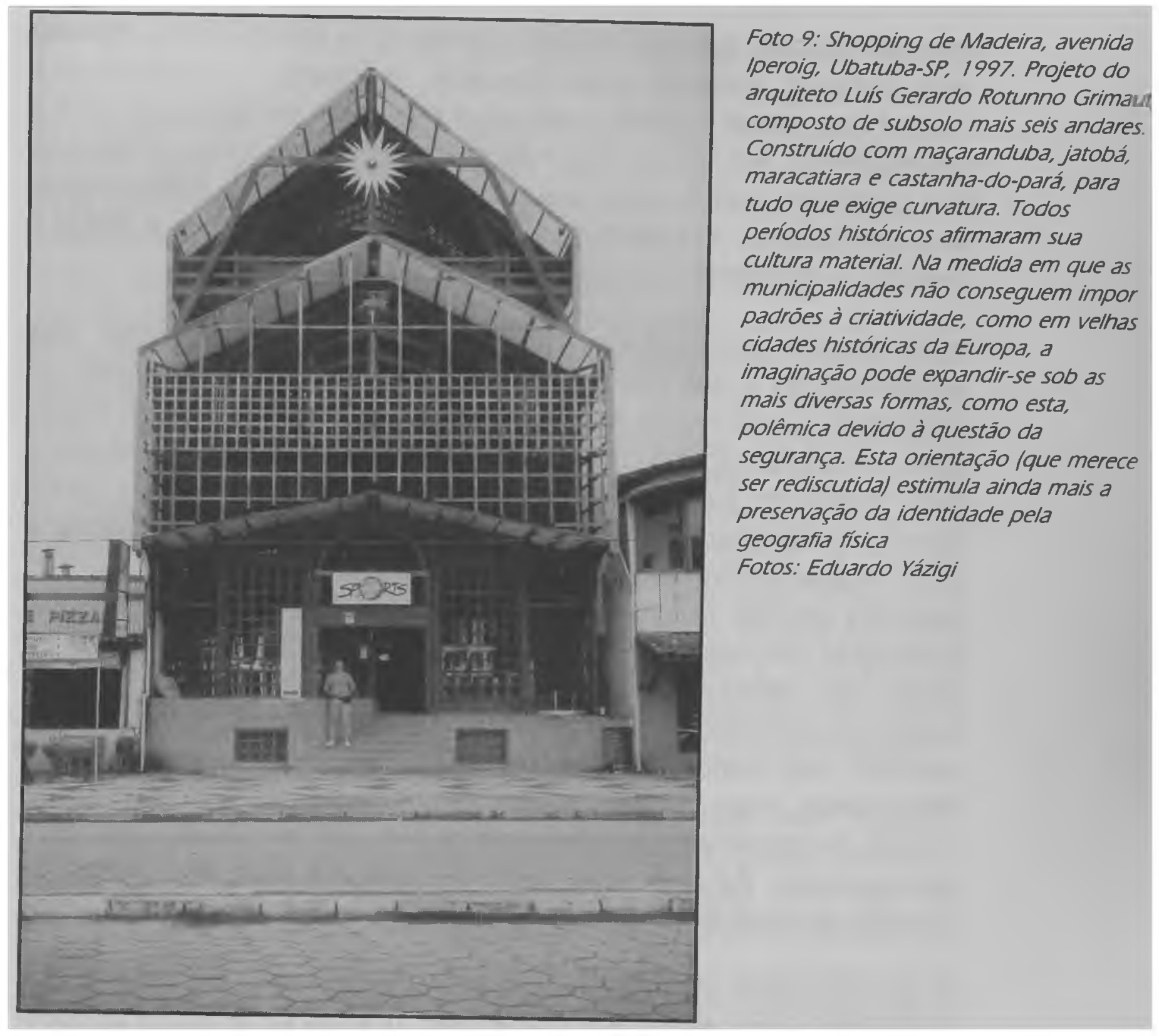

estilos rigorosamente regionais ou até mesmo locais, mas não um que tenha abrangência nacional. Os imigrantes trouxeram a técnica, mas não os materiais, resultando que as primeiras produções no Brasil fossem, inclusive, diferentes das regiōes de origem, chegando a parecer "exóticas" ao alemão que chegasse depois... como bem lembrou Emílio Willems (1946, p. 233). Preferi usar o termo alpinização, em vez de germanização, por ser mais amplo, já que abrange diferentes regiōes de diferentes países. É assim que na realidade, as versōes tropicalizadas dessa suposta arquitetura tomam elementos, indistintamente, da Alemanha, Áustria, Suiça, França, Inglaterra... Um shopping, recentemente inaugurado na praia do Itaguá (foto 10), reúne mescladamente elementos desses países mais a Holanda, declarada num moinho de vento (isto é de origem rural) encravado no meio do 
A Fisiografia e sua Paisagem na Busca da Personalidade do Lugar
Eduardo

Yázigi

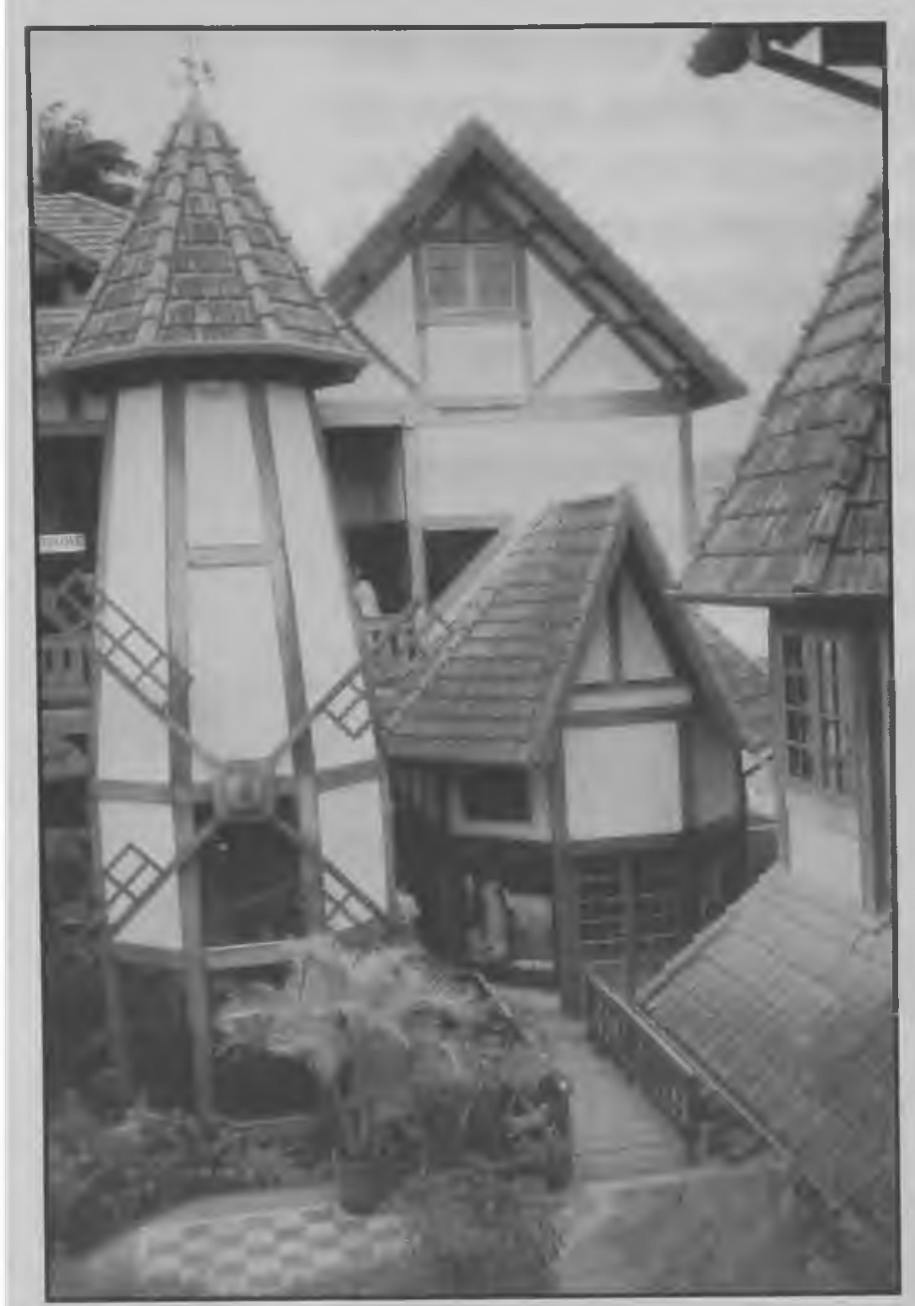

Foto 10: Shopping do Itaguá, Ubatuba-SP, 1997.

Projeto do arquiteto Sidney Giraud. Trata-se do shopping mais concorrido de Ubatuba, cujas fantasias o público se compraz. É o neo-ecletismo em uma única obra: reúne elementos suiços, holandeses e até japoneses, através do espelho de água interno. É a evocação da montanha alpina em plena praia tropical. É mais um dos múltiplos exemplos que com os atuais gerenciamentos urbanos, a preservação da identidade pelo meio natural tende a ser a principal saída para a manutenção da identidade. O mais espantoso é que o autor deste projeto é de origem caiçara $1 . . . \%$ descendente de invasores franceses Fotos: Eduardo Yázigi

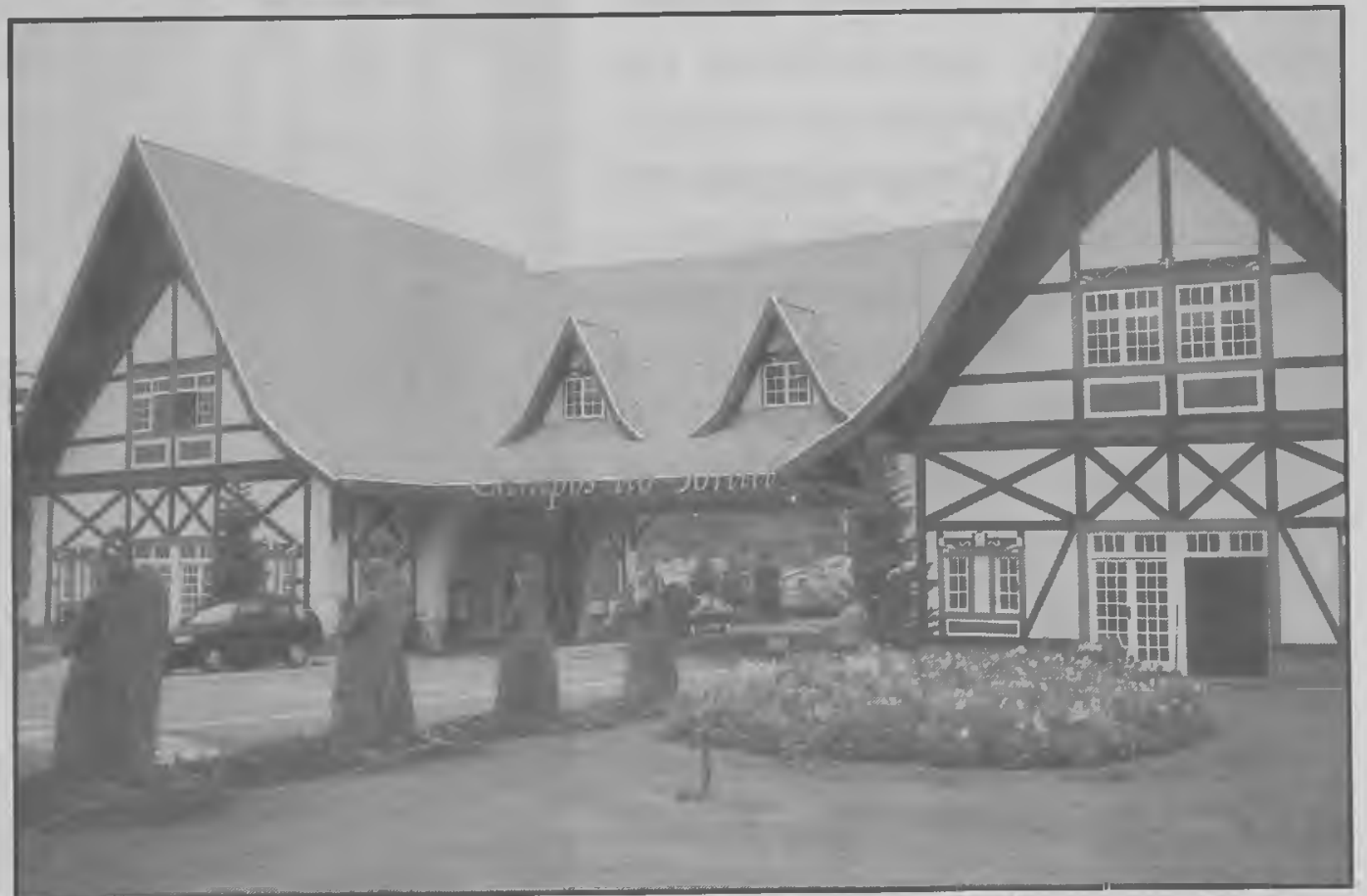

Foto 11: Portal de Campos do Jordão-SP, 1997. As cidades turisticas de montanha no Brasil decidiram que têm de ter um portal nos padrōes do exibido pela foto. $O$ mesmo se repete nas cidades da dita Serra Gaúcha à qualquer localidade "de cima" que assim decida, independentemente de suas histórias. A idéia emibutia, inclusive, a tentativa de vedar entrada de farofeiros

Fotos: Eduardo Yázigi 
estabelecimento urbano, sem possibilidade de vento, tendo por base um laguinho de carpas vermelhas (Japão?) com pedras apostas em forma de dolmen (Irlanda ou Bretanha)... É o neo-ecletismo numa única obra. Importante de ser assinalado é o shopping mais concorrido da cidade. Águas de Lindóia planeja fazer um pórtico de entrada, "estilo suíço" (foto 11), assim como estimular arquiteturas congêneres.

Campos do Jordão, a Suíça brasileira, vem se constituindo no modelo de desenvolvimento urbano para quase todas cidades montanhosas do Brasil. Não se pode negar que para muitos representa um local muito agradável, ainda que só de fachada. Uma arquitetura bem do estilo Branca de Neve (fotos 12 a 22). Em alguns casos, pretende ser mais suiça que a própria Suiça, na medida em que neste país europeu mescla-se uma arquitetura supermoderna em meio à tradicional, fato este intolerável em sua correspondente nos trópicos. Oxalá, Campos de Jordão pudesse realmente ter o genuíno padrão, seria mais do que louvável no contexto do subdesenvolvimento! Mas resulta que Campos se trai em muitos aspectos da esfera pública: calçadas e vias carroçáveis esburacadas; lixo mal resolvido (foto 23); atendimento muito precário de toda rede pública de saúde e educação; transportes sofríveis... Mas mesmo assim, até as casas de pobres se helvetizam segundo o modelo superior...(foto 24). O centro do bairro de Capivari é uma exacerbação da Suíça; vila Jaguaribe e Abernéssia bem menos. Abandonou-se um estilo arquitetônico que Ihe era muito característico (fotos 25 e 26) pelo modelo fantasioso. Mas quer a crítica gos-

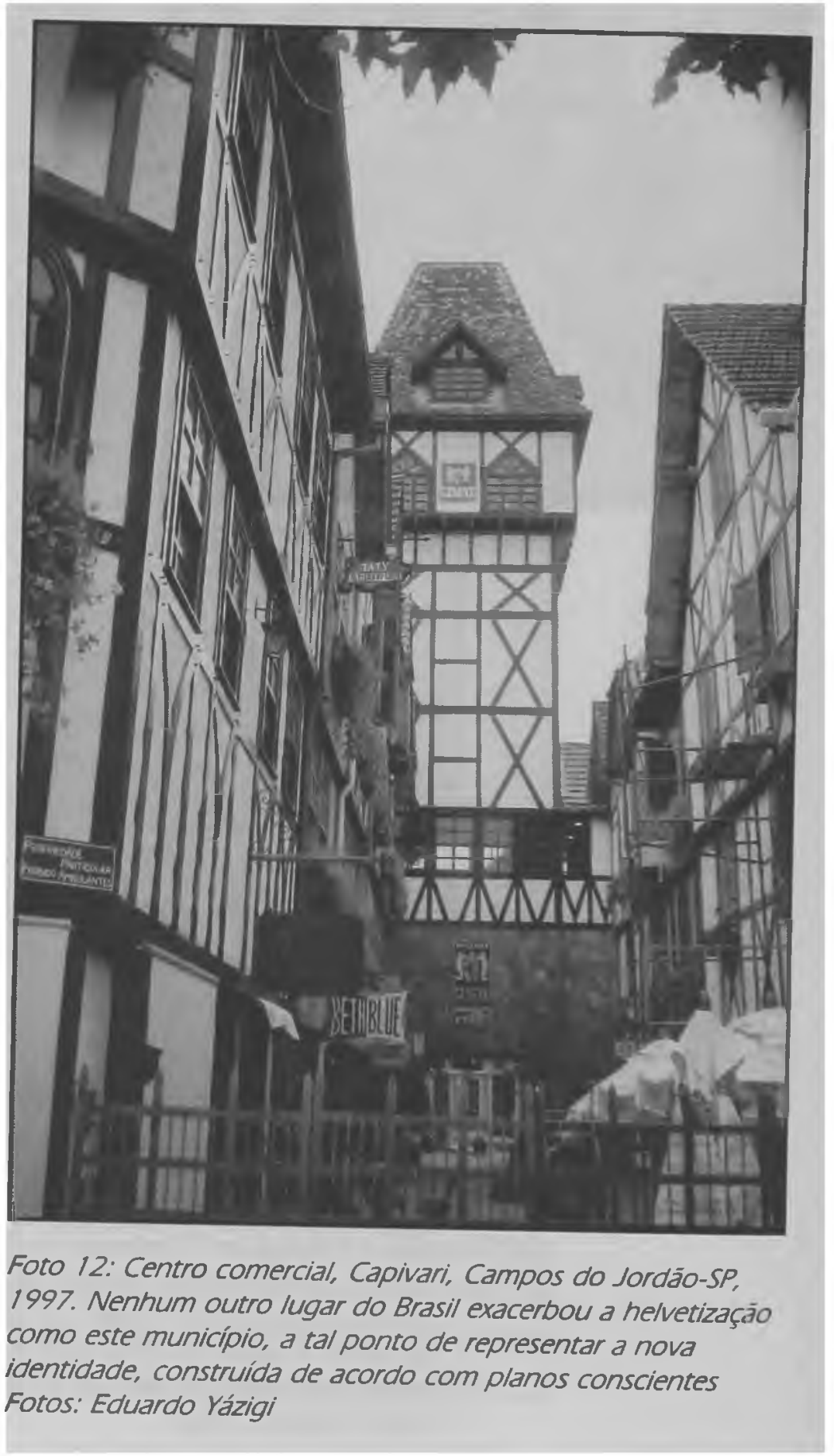

\begin{tabular}{|c|c|c|}
\hline 84 & Paisagem & São Paulo n. 11 p. 71 - 98 dez. 1998 \\
\hline & $\begin{array}{l}\text { Ensaios } \\
11\end{array}$ & \\
\hline
\end{tabular}


te ou não, esta é a nova identidade de Campos do Jordão e, ao que parece, irreversível, além de exemplar ${ }^{1}$

Há um fato inegável que temos de reconhecer. A história de muitos países da Europa tem tal densidade e importância universal que não pode ser posta de lado. Em outras palavras, arquitetos de lá parecem aceitar sem muita discussão que a preservação, inclusive com o custo da liberdade de criação, tem de ser um fato obrigatório. Mas também, quando surge um Scarpa, Verona sabe muito bem dar-Ihe o lugar merecido. Do lado brasileiro, claro que nossa história tem importância, pois só temos essa; foi ela que nos moldou. Mas como ela é também uma reconstrução, como também o mais importante das produções anteriores foi demolido, é lícito perguntar sobre qual estilo se apoiar. Salvo raras construções coloniais com alguma presença no centro de São Sebastião, em Ilhabela e Caraguatatuba elas se contam nos dedos. Em Caraguatatuba tudo foi sumariamente descaracterizado. Nas cidades pesquisadas da Serra da Mantiqueira, o chamado estilo colonial hrasileiro pareceria aberração no contexto do que tem sido produzido: alpinização generalizada em Campos do Jordão, a ponto de tornar-se sua verdadeira identidade atual. São Bento do Sapucaí ensaia caminhar pelos mesmos trilhos e Águas de Lindóia, que com apenas algumas incursões na área alpina, já tem sua identidade marcada pelo arranha-céu de São Paulo. Quanto a São Bento do Sapucaí, caberia lembrar que um de seus traços históricos característicos lque a maioria das cidades seculares do Brasil conheceram), portanto de identidade, consiste no simples fato de possuir casas com fachadas que dão na calçada. Seja, quando mais da metade de uma testada estiver em tal situação, seria o caso de assim manter (fotos 27 a 31). No entanto, a municipalidade ignora tal princípio, já que sua lei orgânica não prevê tal destinação - em detrimento da personalidade do lugar. Num dos mais recentes planos diretores de Caraguatatuba, aliás, há perspectiva de uma avenida que imita a avenida Paulista de São Paulo, especialmente no trecho da passagem de nível com lages de concreto, entremeadas de vazios...

No entanto, para quem quiser ver, além de toda essa arquitetura está a exuberância da Serra do Mar e todos recortes do litoral norte do estado de São Paulo. Está ainda a magnificente Serra da Mantiqueira 
Eduardo Yázigi
A Fisiografia e sua Paisagem na

Busca da Personalidade do Lugar

Foto 13: Centro comercial, Capivari, Campos do Jordão-SP, 1997. Note-se a insistência da palavra Geneve para reafirmar

o mundo suiço. $O$ uso exagerado do madeirame externo torna-se motivo de marketing imobiliário Foto: Eduardo rázigi

Foto 14: Restaurante Baden Baden, Capivari, Campos do Jordão-SP, 1997. Nem só da Suíça vive Campos do Jordão, mas de qualquer coisa da Europa fria.

Note-se a bandeira da Alemanha Foto: Eduardo Yázigi
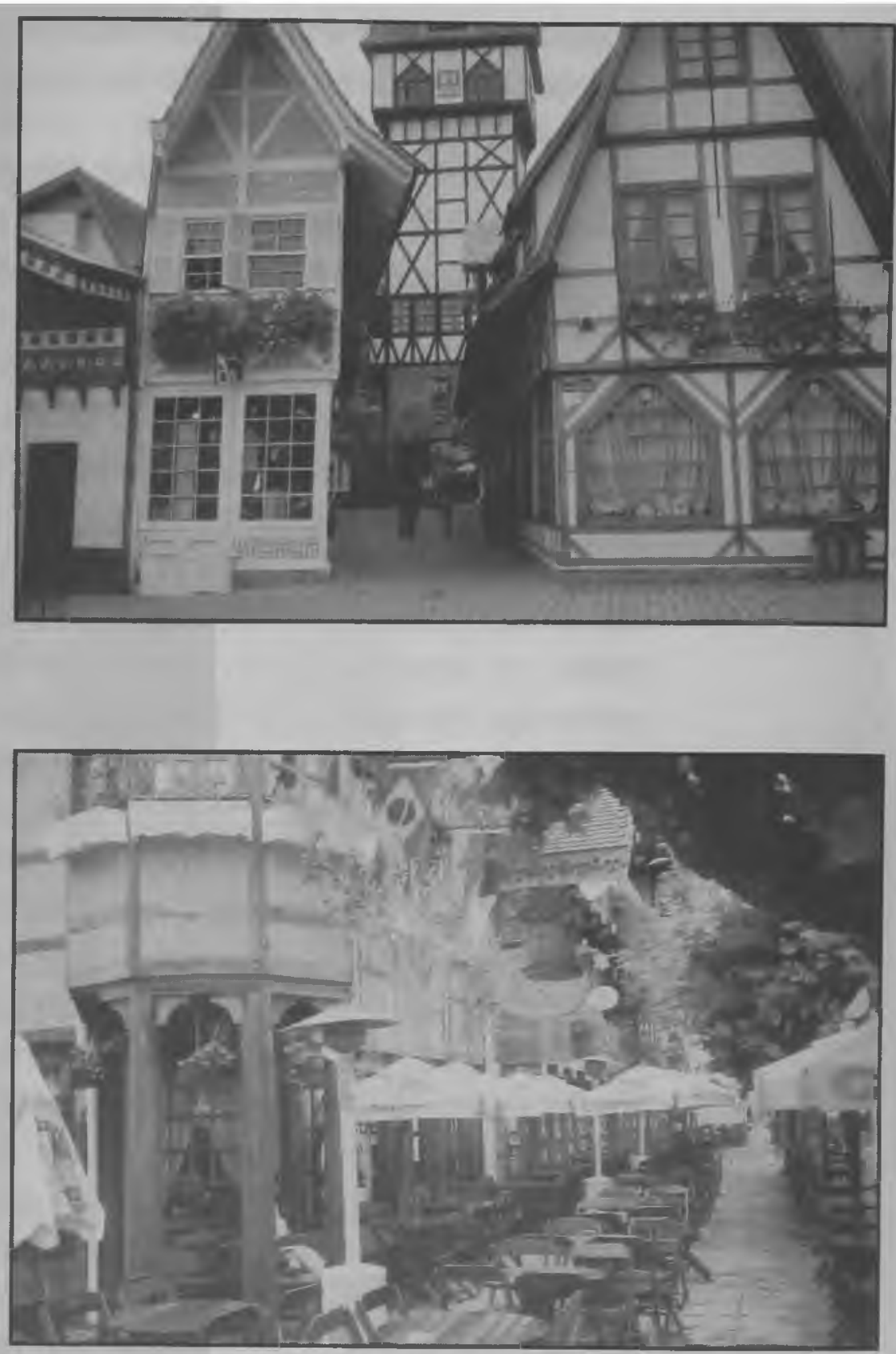

Foto 15: Centro comercial, Capivari, Campos do Jordâo-SP, 1997. Neste centro, a evocação é de Aspen, estação de inverno dos Estados Unidos Foto: Eduardo Yázigi

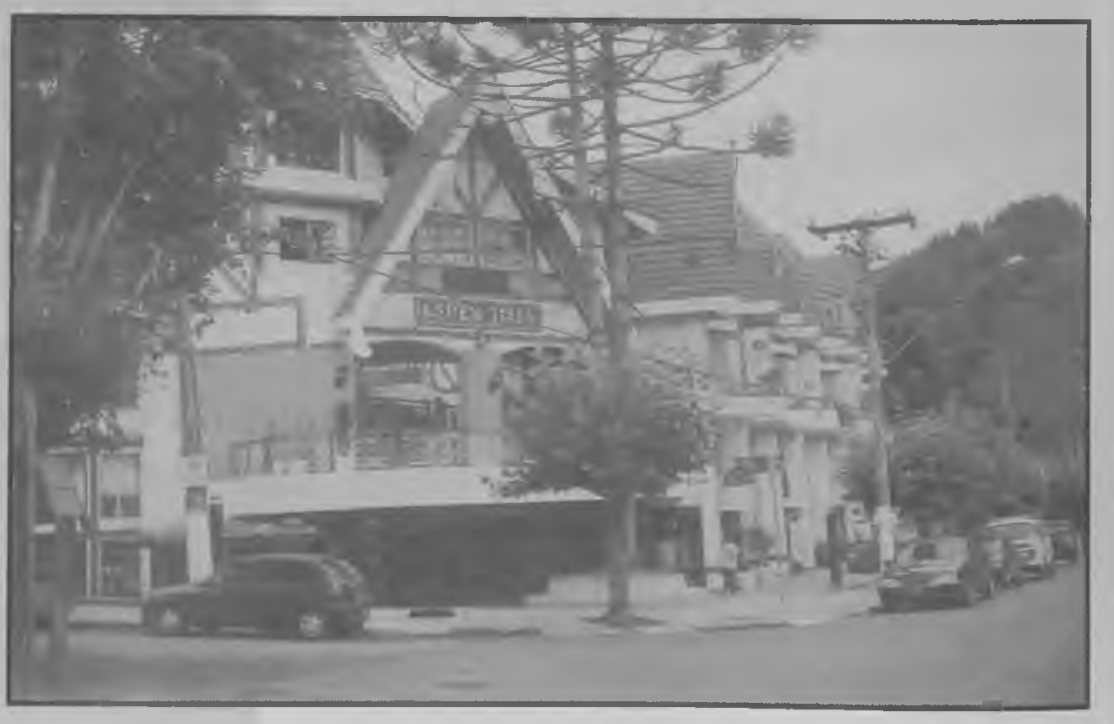

São Paulo n. 11 p. $71 \quad 98$ dez. 1998 
A Fisiografia e sua Paisagem na Busca da Personalidade do Lugar
Eduardo Yázigi
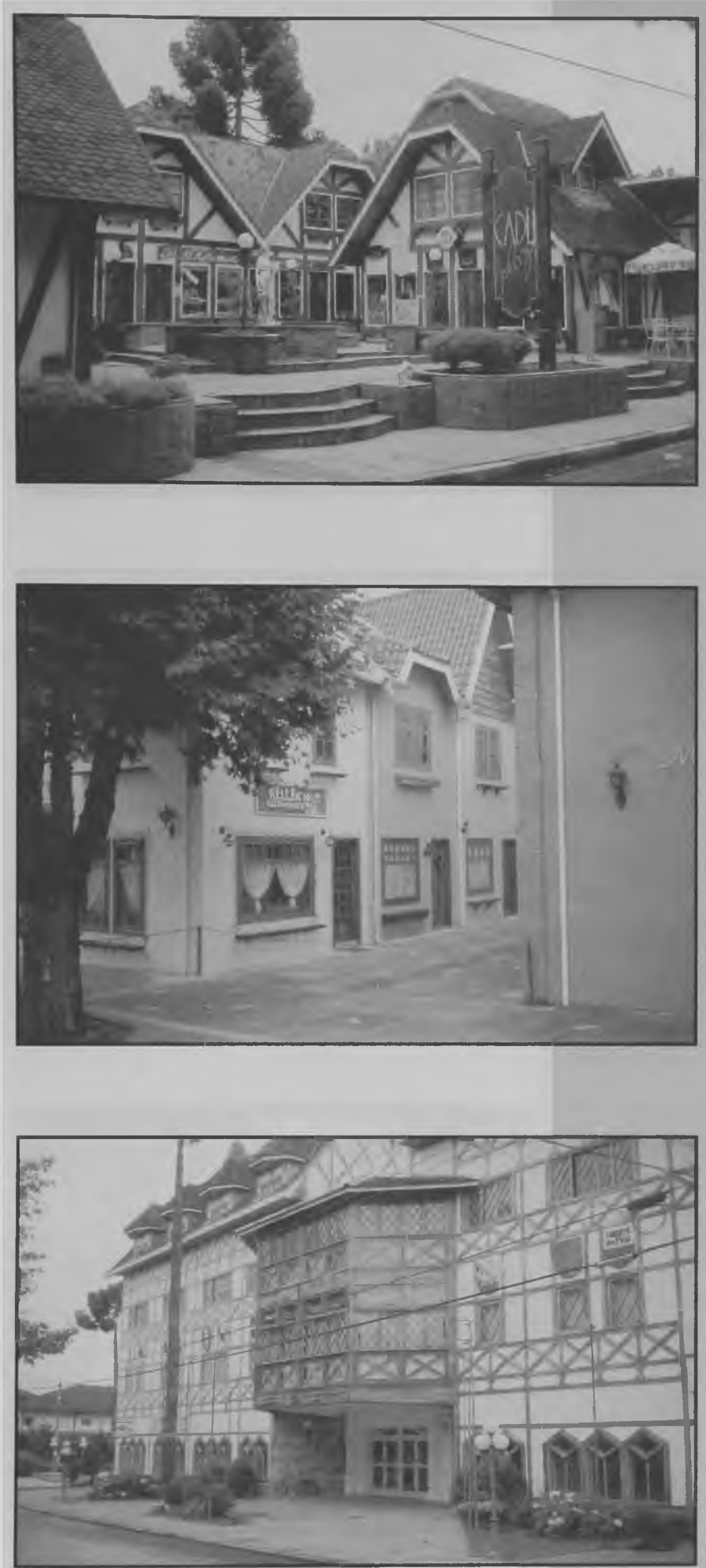

Foto 16: Centro comercial, Capivari, Campos do Jordão-SP, 1997. Aqui os elementos pós-modernistas se mesclam ao ambiente alpino Foto: Eduardo Yázigi

Foto 17: Passagem comercial, Capivari, Campos do Jordäo-SP, 1997, com diversificação arquitetônica, que tanto pode ser a própria Suíça como a Holanda Foto: Eduardo Yázigi

Foto 18: Centro comercial, avenida Macedo Soares, Capivari, Campos do Jordâo-SP, 1997

Foto: Eduardo Yázigi 
Eduardo Yázigl
A Fisiografia e sua Paisagem na

Busca da Personalidade do Lugar

Foto 19: Edifício de apartamentos, Capivari, Campos do Jordão-SP, 1997. A municipalidade estabeleceu o gabarito de quatro andares, a fim de preservar a construção da identidade em curso Fotos: Eduardo Yázigi

Foto 20: Habitaçōes unifamiliares, Capivari, Campos do Jordāo-SP, 1997 Fotos: Eduardo Yázigi

Foto 21: Residência secundária de turistas, São Bento do Sapucaí-SP, 1997. Como sua vizinha Campos do Jordão, dá boas vindas a tudo que the seja similar, mesmo em detrimento da cultura local Fotos: Eduardo Yázigi
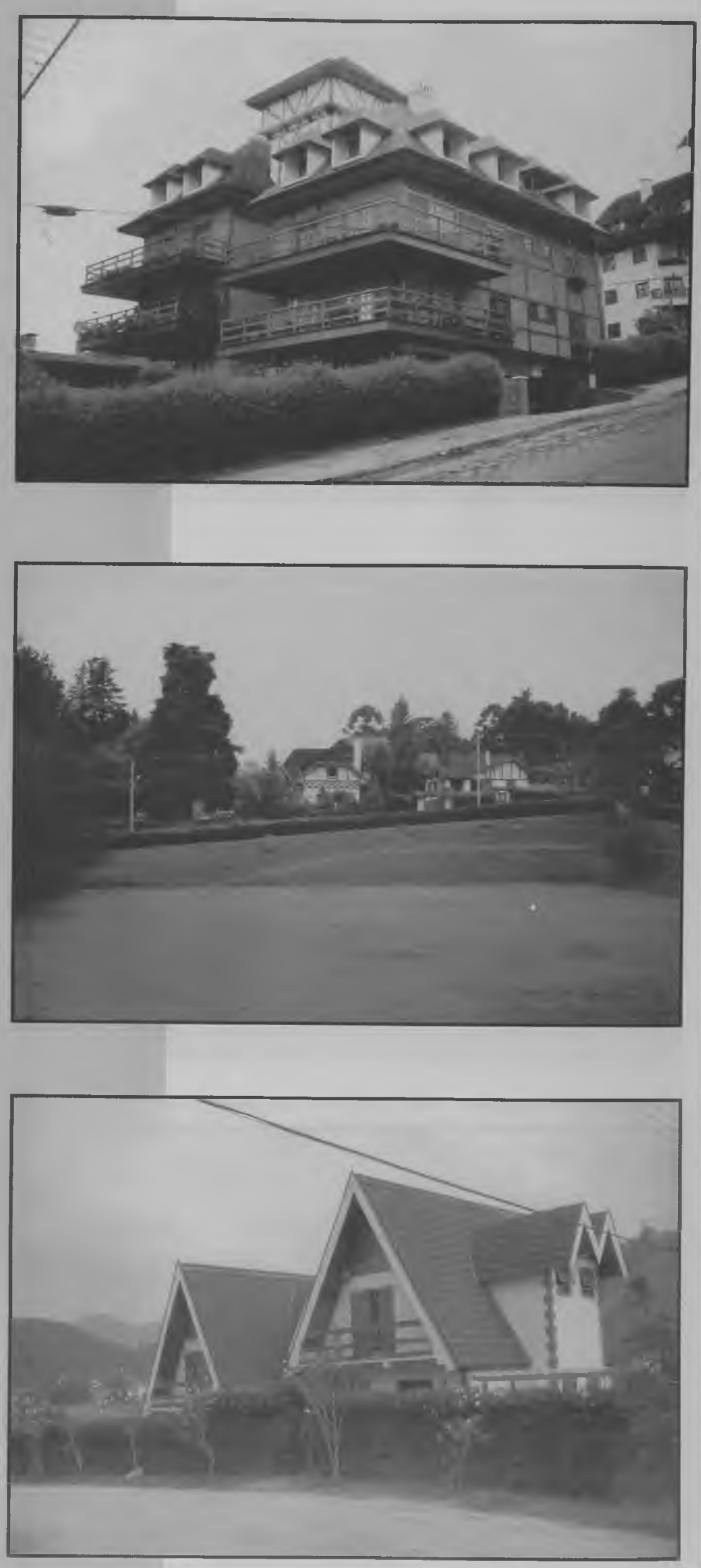

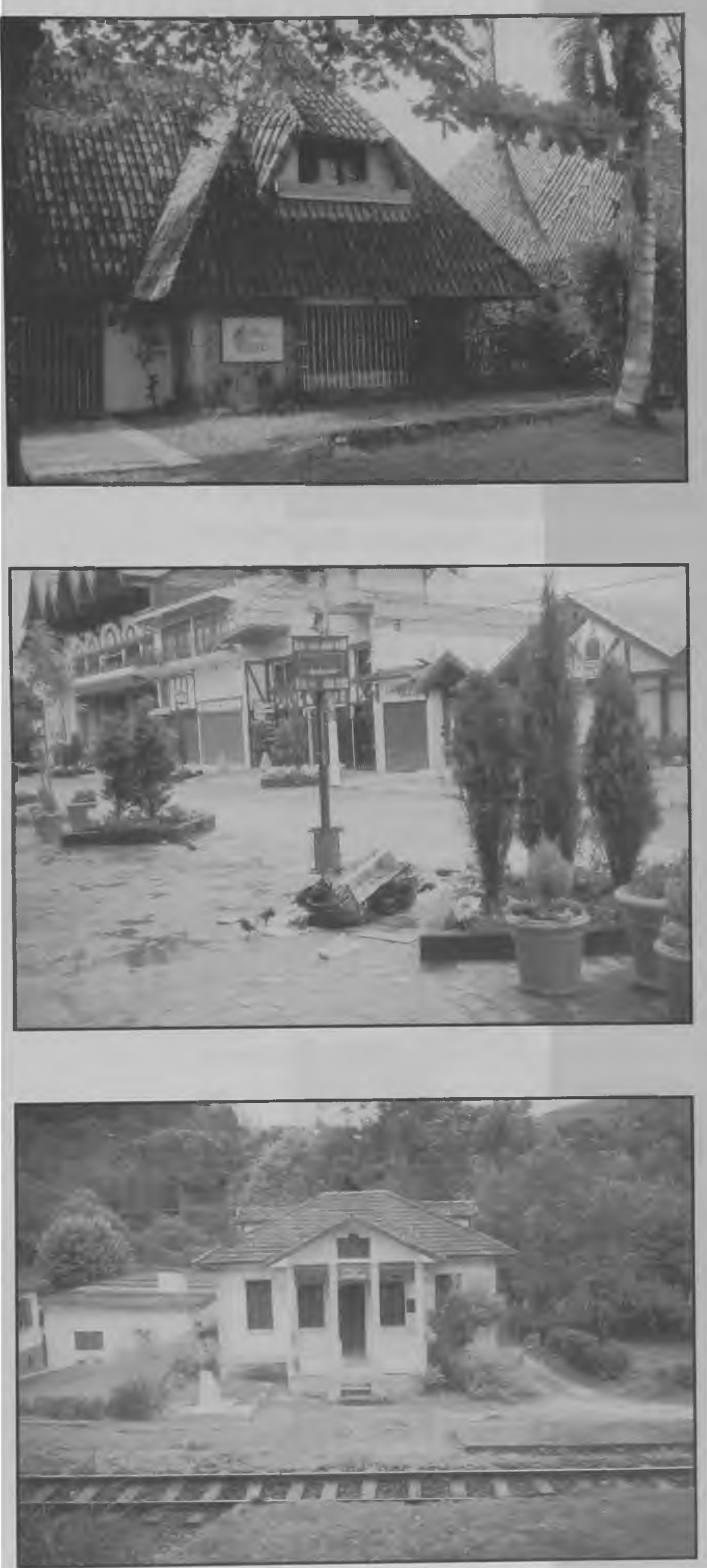

Foto 22: Pousada na Praia do ltaguá, Ubatuba-SP, 1997, com telhado para escorrer a neve... Um projeto evocando montanha nevada da Europa, mas com ampla receptividade do usuário Fotos: Eduardo Yázigi

Foto 23: Centro de Capivari, Campos do Jordão-SP, 1997. O padrão suíço se resume a meras fachadas para turistas. O comportamento do cidadão le da rede de serviços públicos) não tem muitos compromissos com o modelo que pretende reproduzir Fotos: Eduardo Yázigi

Foto 24: Museu da Tuberculose, Capivari, Campos do Jordão-SP, 1997. Este era padrão de arquitetura burguesa mais desenvolvida, antes do fenômeno turístico. Foi sendo progressivamente abandonado com a alpinização

Fotos: Eduardo Yázigi 
Eduardo Yázigi
A Fisiografia e sua Paisagem na

Busca da Personalidade do Lugar

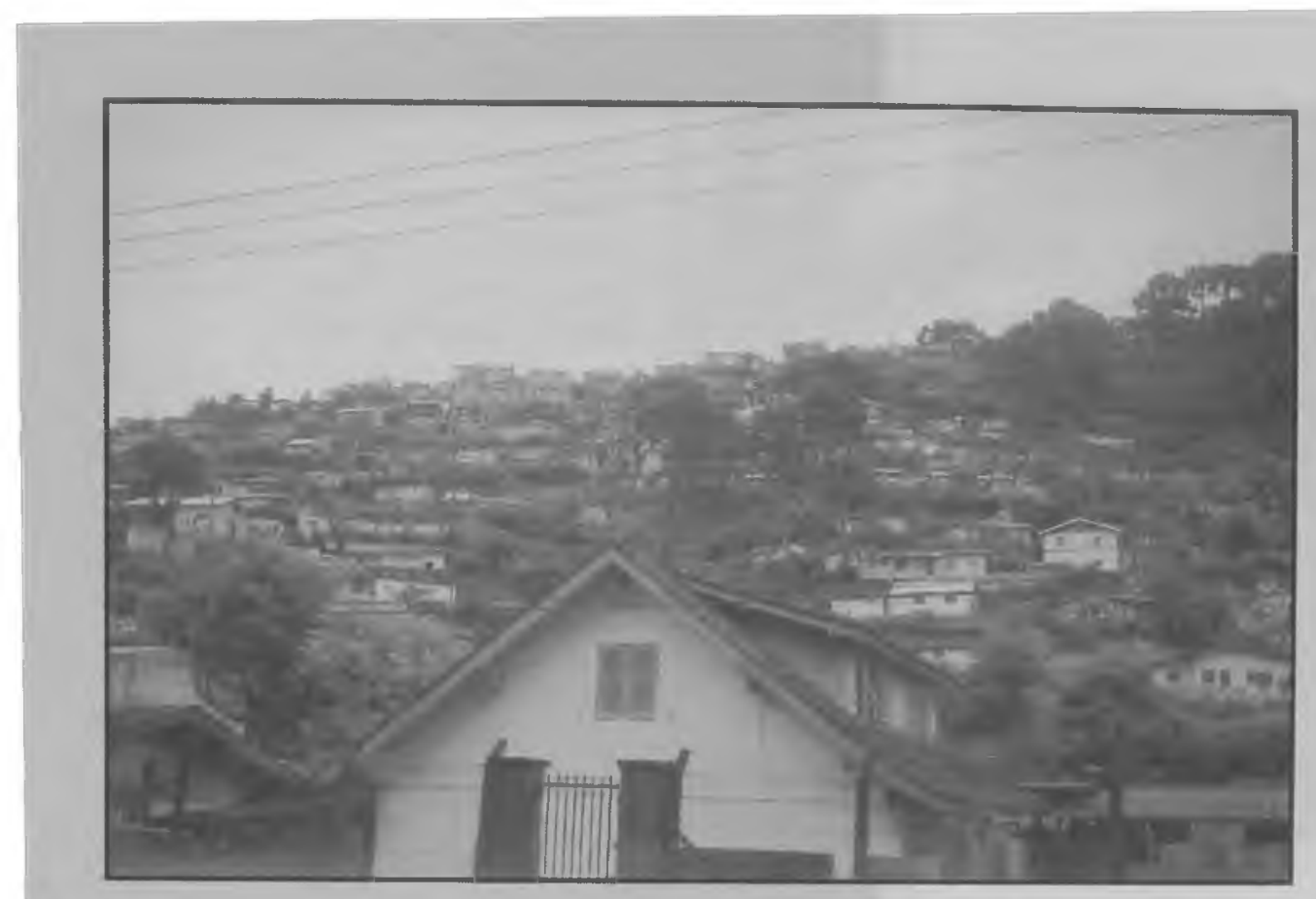

Foto 25: Morro com habitações populares em Abernéssia, Campos do JordãoSP. 1997. Aos poucos uma e outra construção de gente do lugar vai incorporando elementos de fachada do estilo alpino, reproduzindo o esquema que a arquitetura popular do período áureo do café conseguiu lpor exemplo, criando a colunata no lugar de colunas, por falta de recursos e espaço/ Fotos: Eduardo Yázigi

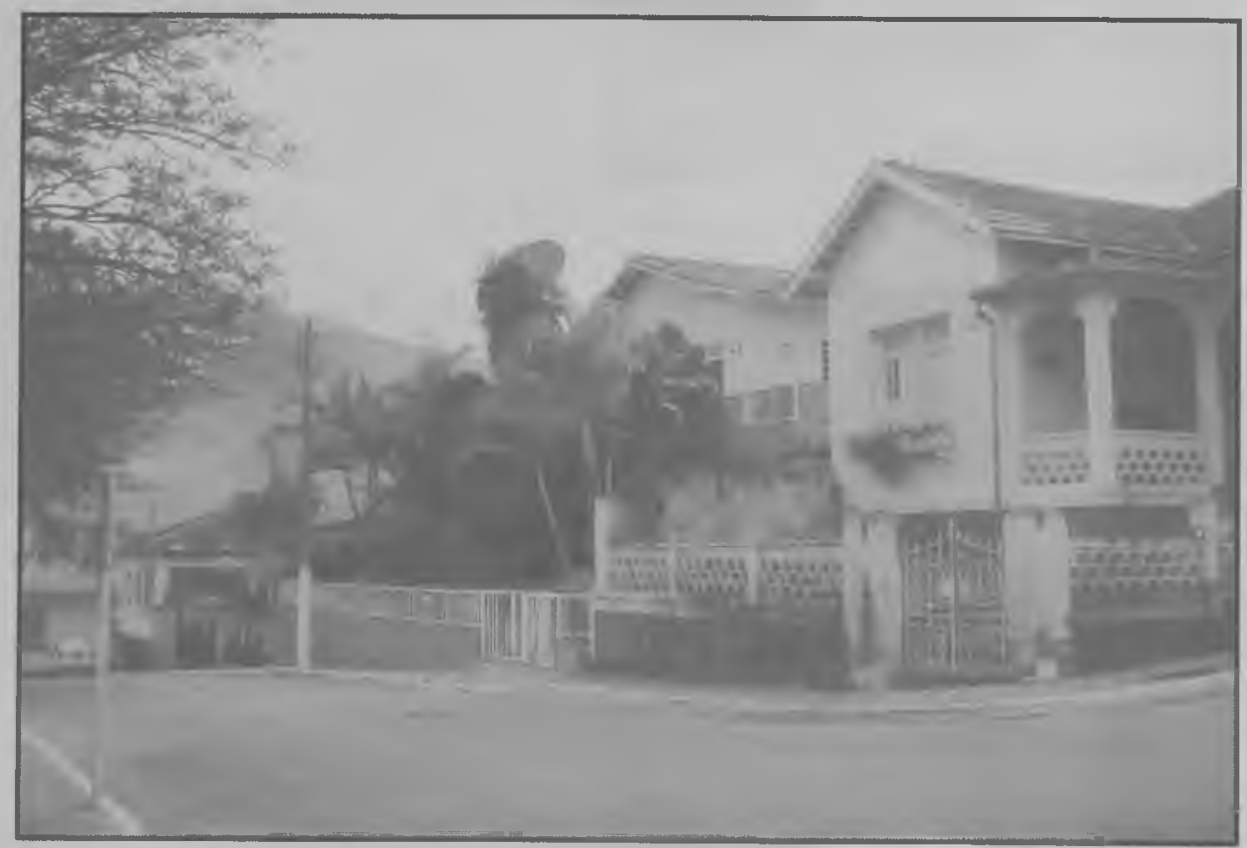

Foto 26: Casas burguesas de São Bento do Sapucai-SP, 1997. Como em Campos do Jordão, sobraram poucos exemplares, em detrimento da alpinização

Fotos: Eduardo Yázigi

\begin{tabular}{|l|l|}
\hline 90 & Paisagem \\
\cline { 2 - 2 } & Ambiente \\
Ensaios \\
11
\end{tabular}

São Paulo n. 11 p. 7198 dez. 1998 
com suas paisagens de rara beleza. Tais presenças, face a ausência histórica de rumos definidos na arquitetura, parece impor a geografia física como única possibilidade de oficializar a paisagem (fotos 32 a 34). A urbanização já foi de tal monta que se torna impensável, salvo no caso de São Bento do Sapucaí, anular o que já está inscrito. No entanto, na medida em que se aceita a fisiografia como elemento mais forte da nova identidade, tem-se várias conseqüências: a) a arquitetura e o urbanismo, respeitando as premissas ecológicas, serão gerados segundo esta diretriz; b) a necessidade de preservar as grandes reservas tanto da Serra da Mantiqueira, como do litoral, exigem o equacionamento da questão social do caiçara e do caipira, ainda perceptível nos bairros rurais das montanhas. São tipos humanos que se modificaram e foram acrescidos de imigrantes em busca de trabalho: os mineiros e nordestinos são facilmente notados no litoral, onde são acusados de ocupar os sopés das encostas, onde começam as reservas. Moram lá, não porque querem, mas porque não têm outro lugar. Digo isto porque muitos intelectuais pretendem, por exemplo, que caiçaras devam mesmo coletar recursos de vida das reservas, criticando-as por terem sido feitas nos moldes americanos.

Há várias considerações a serem feitas, tocante a esta última asserção. Em primeiro lugar, o caiçara, definido por vários autores como o caipira do litoral, aquele que vive da pequena lavoura e da pesca, quase não existe mais. São Sebastião é representativa: apenas mil, em quarenta mil de seus habitantes são rurais. Quem é caiçara? Conheci uma nissei de poucos recursos que vende pizza no litoral de São Sebastião. Ela é caiçara?... Autodenominam-se caiçaras, isto sim, empregados de hotéis e restaurantes, frentistas, motoristas, etc. Não me parece razoável que se sacrifique a identidade dada pelas reservas (além de únicas no mundo, fonte do turismo que os alimenta) em nome de meras coletas. Parece-me muito estranho que mais de vinte mil anos depois de o homem ter inventado a agricultura se reclame a volta da coleta. $O$ problema que tem de ser enfrentado é o da pobreza; o da incapacidade de suprimento de serviços essenciais; de boas políticas habitacionais e não o de manutenção de um jeito primitivo de se viver, que aliás, nem eles querem mais. Pode-se, isto sim como já está sendo feito, graças a algumas associações e sindicatos, promover plantações de caxeta, por exemplo, própria para seus artesanatos. Já não vejo aquelas idílicas cenas de caiçaras conversando à beira-mar, com a luz do luar e vivendo só do setor primário. São pessoas como nós laté adquirindo os mesmos vícios de consumo...) invadidas pelas mídias. São pessoas que querem

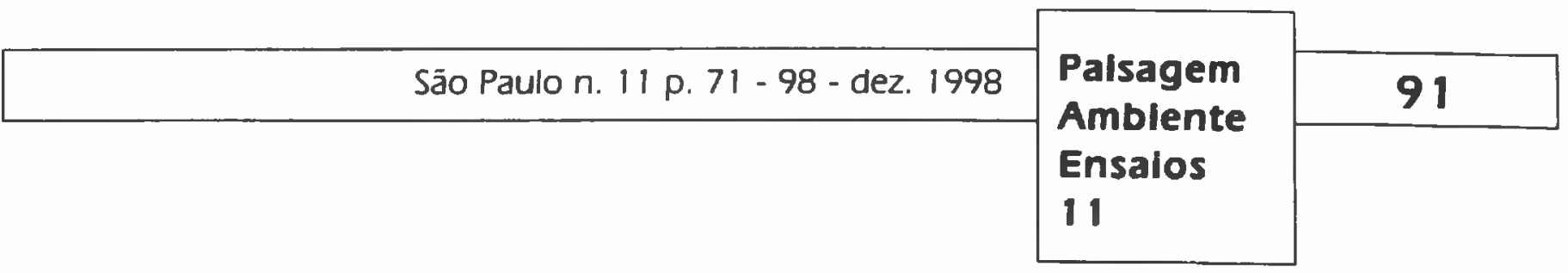




\section{Eduardo \\ Yázigi}

A Fisiografia e sua Paisagem na

Busca da Personalidade do Lugar

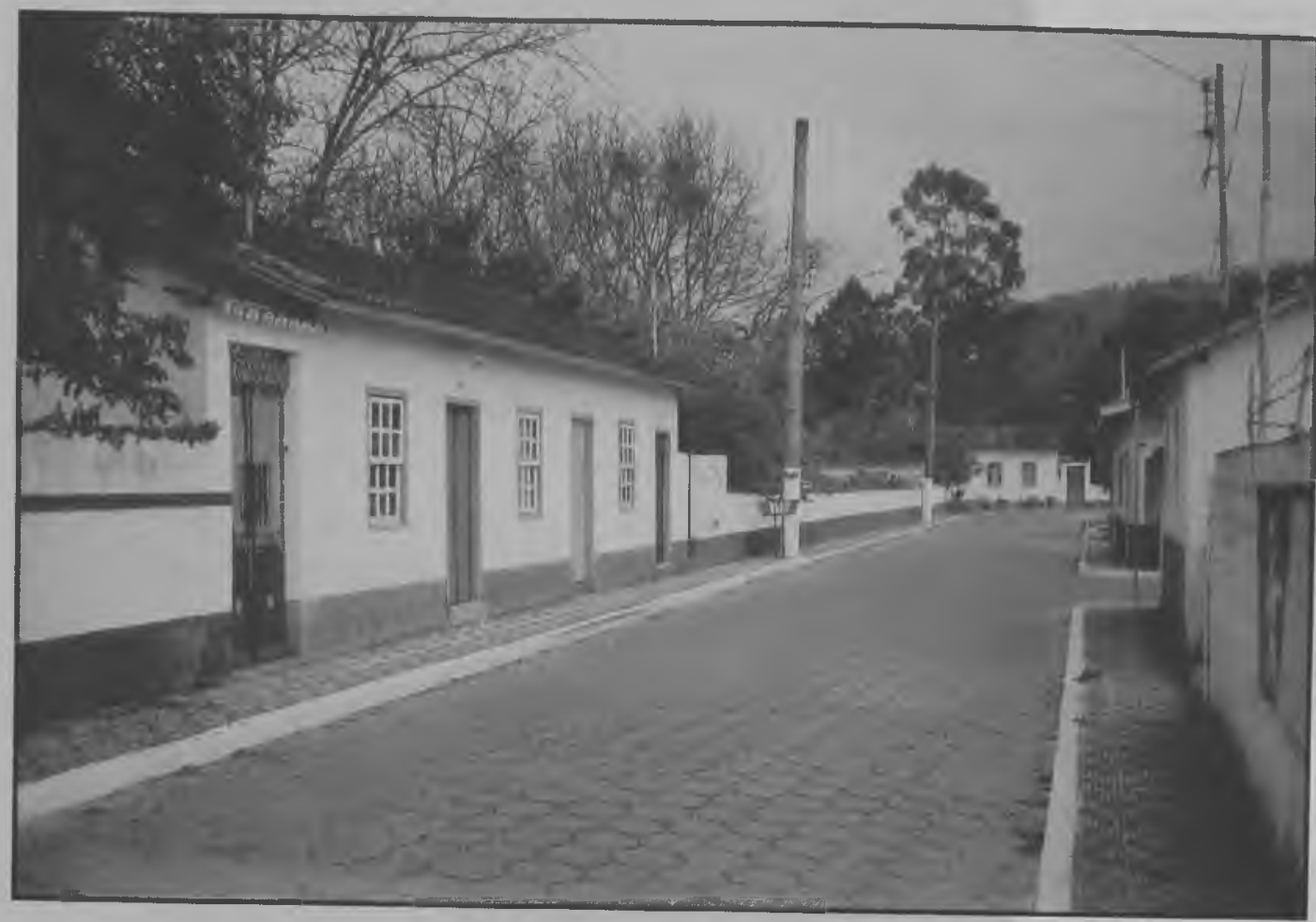

Foto 27: Pousada das Nogueiras, São Bento do Sapucai-SP, 1997. Antigas casinhas foram revalorizadas por iniciativa particular. mantendo-se no alinhamento da rua - uma identidade local preservada Fotos: Eduardo Yázigi

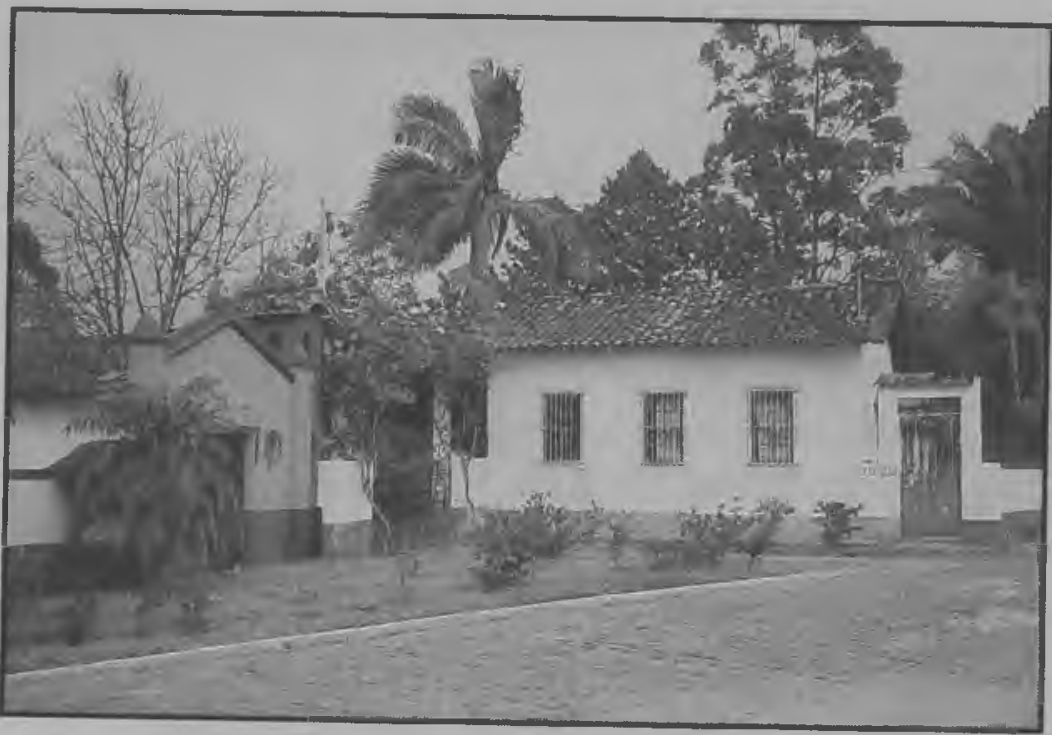

Foto 28: Pousada das Nogueiras,

São Bento do Sapucai-SP, 1997.

Capelinha e casa principal

Fotos: Eduardo Yázigi

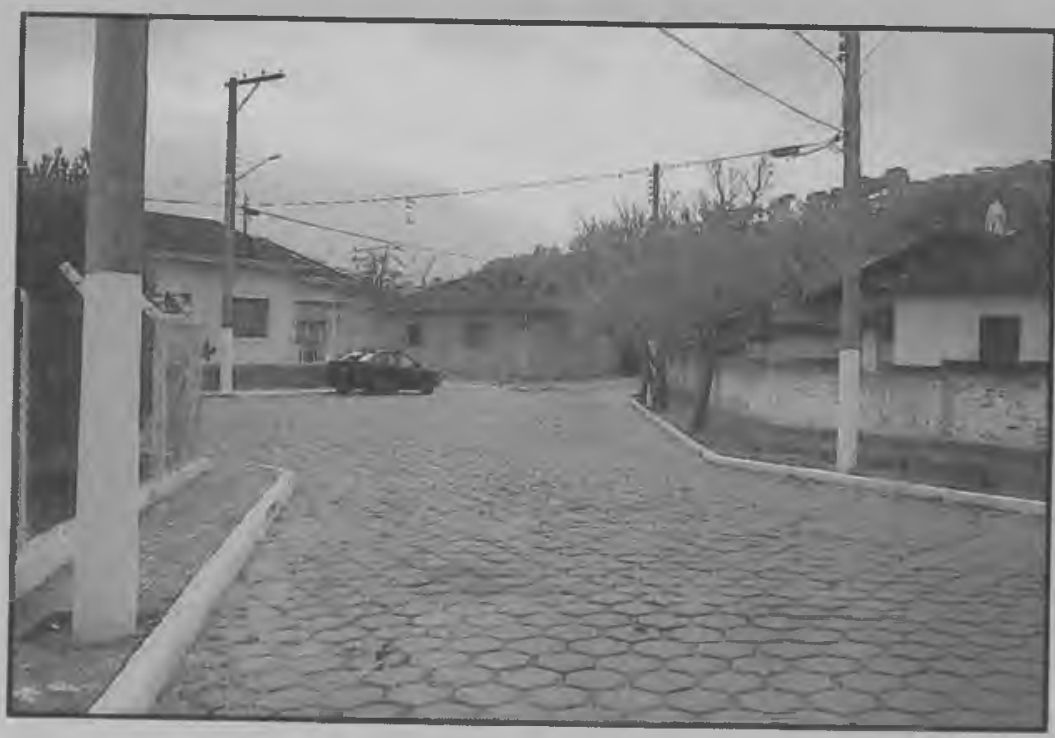

Foto 29: São Bento do Sapucai-SP. 1997. A cidaide apresenta vários trechos com sistema viário desalinhado, testemunho de outros tempos. O centro urbano, neoclássico, de Spétezes, Grécia, soube tirar partido disto magistralmente. Em São Bento de Sapucaí, até o momento, soube-se evitar o realinhamento, 0 tudo retinho, tão do gosto dos prefeitos brasileiros... Isto também é identidade! Fotos: Eduardo Yázigi 


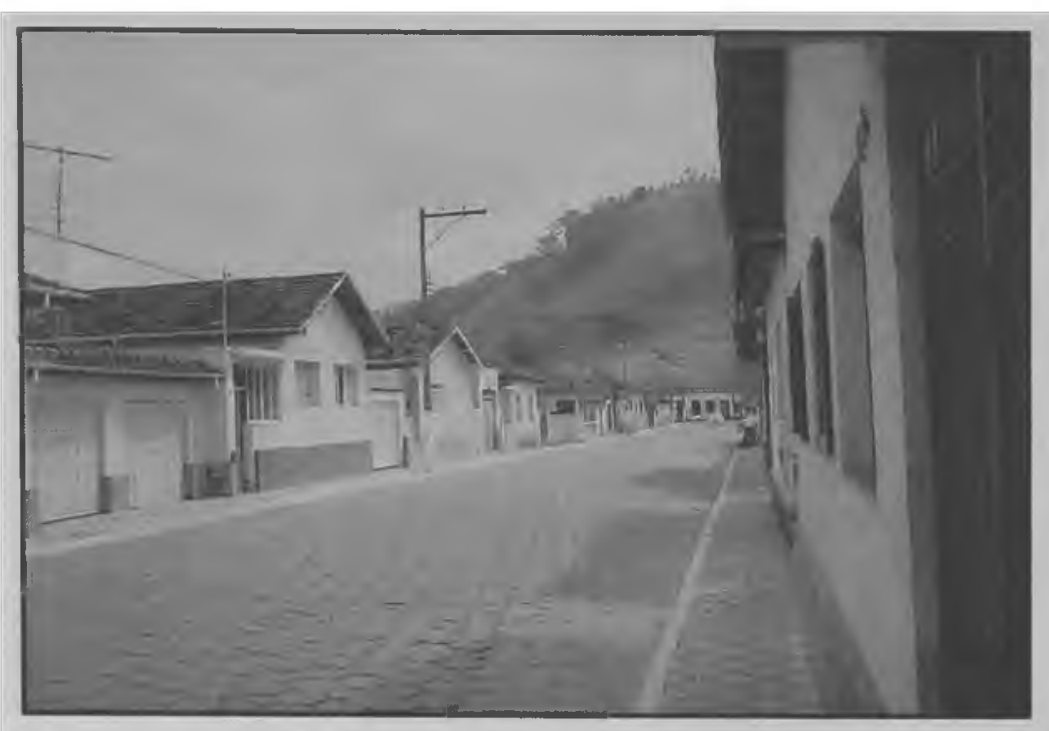

Foto 30: São Bento do Sapucaí-SP, 1997. Casas dando na rua são identidades a serem preservadas - neste caso por circunstâncias de particulares

Fotos: Eduardo Yázigi

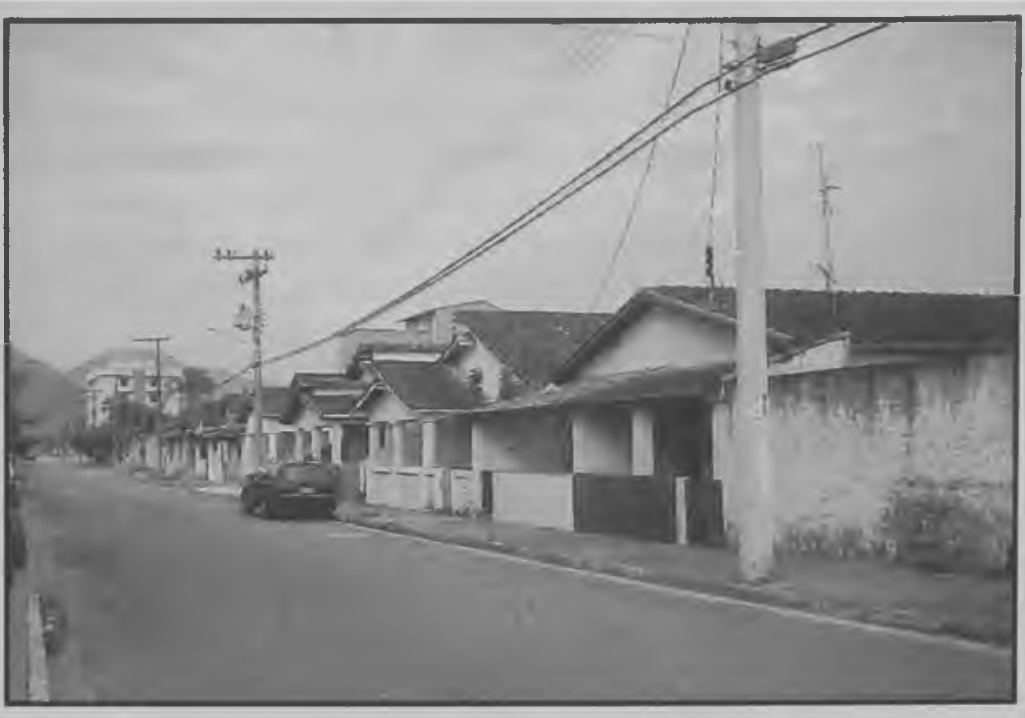

Foto 31: Praia do Itaguá, Ubatuba-SP, 1997. Casario preservado, com amparo da lei de uso e ocupação do solo municipal, promulgada em 1978. Hoje em dia, um lugar pode ter várias identidades Fotos: Eduardo Yázigi

um futuro melhor para os filhos, não nos sertōes, mas nas faculdades... Quanto ao caipira, é mais infeliz ainda, pois enquanto o caiçara é idealizado, poucos fazem uma apologia do caipira. Caipira, nos padrões estudados por Antonio Cândido (1979) e Maria Isaura de Queiroz (1973), ao contrário do fazendeiro, produzia para consumir e vender apenas os excedentes (foto 35). Tinha a vida organizada em mutirões, nas esferas das capelas e dos bairros rurais. Este tipo, também, mal é percebido nos municípios estudados. Para finalizar esta questão, que não é a única identidade a ser observada, parece-me que a melhor via consiste, sem possibilidade de dissimulações, em suas reais participações nas esferas de planejamento municipal, no sentido de ter seu território realmente engrandecido pelo dado espacial, fato este de estreita ligação com a cidadania. No mais, tudo o que não for objeto de planejamento territorial se resolverá por outra instância do poder, não sendo pois da alçada do paisagismo.

\section{Uma diretriz de respeito ao meio natural}

Tenho preferido a expressão "de respeito ao meio natural" à "ecologia" por causa das desvirtuações deste último termo: tudo pode ser 
Eduardo Yázigi
A Fisiografia e sua Paisagem na Busca da Personalidade do Lugar

Foto 32: Ubatuba-SP, 1997, vista do Itaguá. O litoral norte paulista é de uma exuberância inconteste. Esta é sua principal identidade. Lamentavelmente,

vistas como esta vão sendo possíveis, apenas a partir de pontos restritos, especialmente no meio muito urbanizado Fotos: Eduardo Yázigi

Foto 33: Ubatuba-SP, 1997, vista do Itaguá. Foto tomada de outro ponto da mesma praia, onde um grande parque de diversōes, de gosto dividoso, não só obsta a visão no trecho mais nobre da cidade, como priva o cidadão de circular mais livremente no espaço público Fotos: Eduardo rázigi

Foto 34: Foz de rio no centro de UbatubaSP, 1997. Tradicionalmente, este seria um dos pontos altos da identidade a serem revalorizados como porto comercial, inclusive com sua função pesqueira. No entanto, pontes e passarelas inviabilizaram a passagem de vários tipos de embarcaçōes outrora acessíveis. Mais uma displicência da administração local Fotos: Eduardo Yázigi
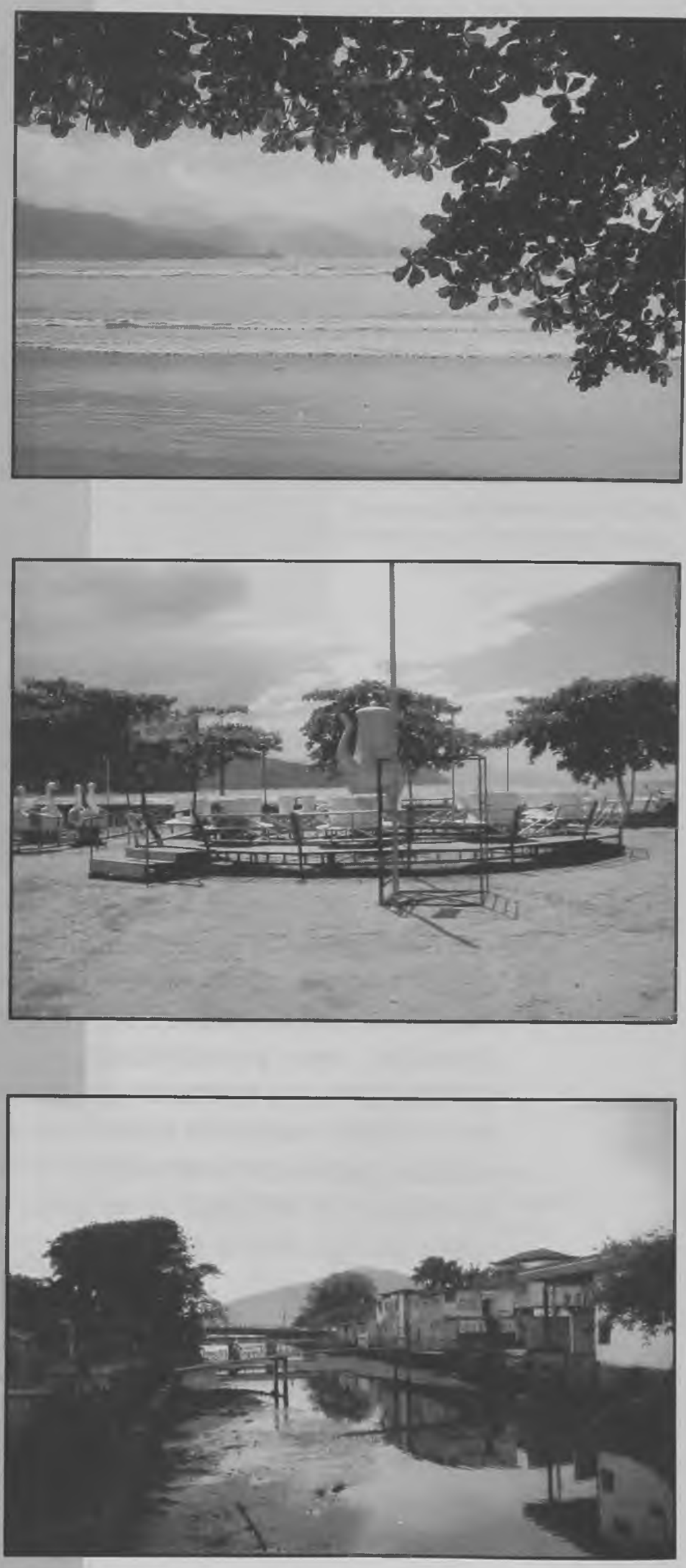

\section{Paisagem Ambiente Ensaios

São Paulo n. 11 p. $71 \quad 98$ dez. 1998 


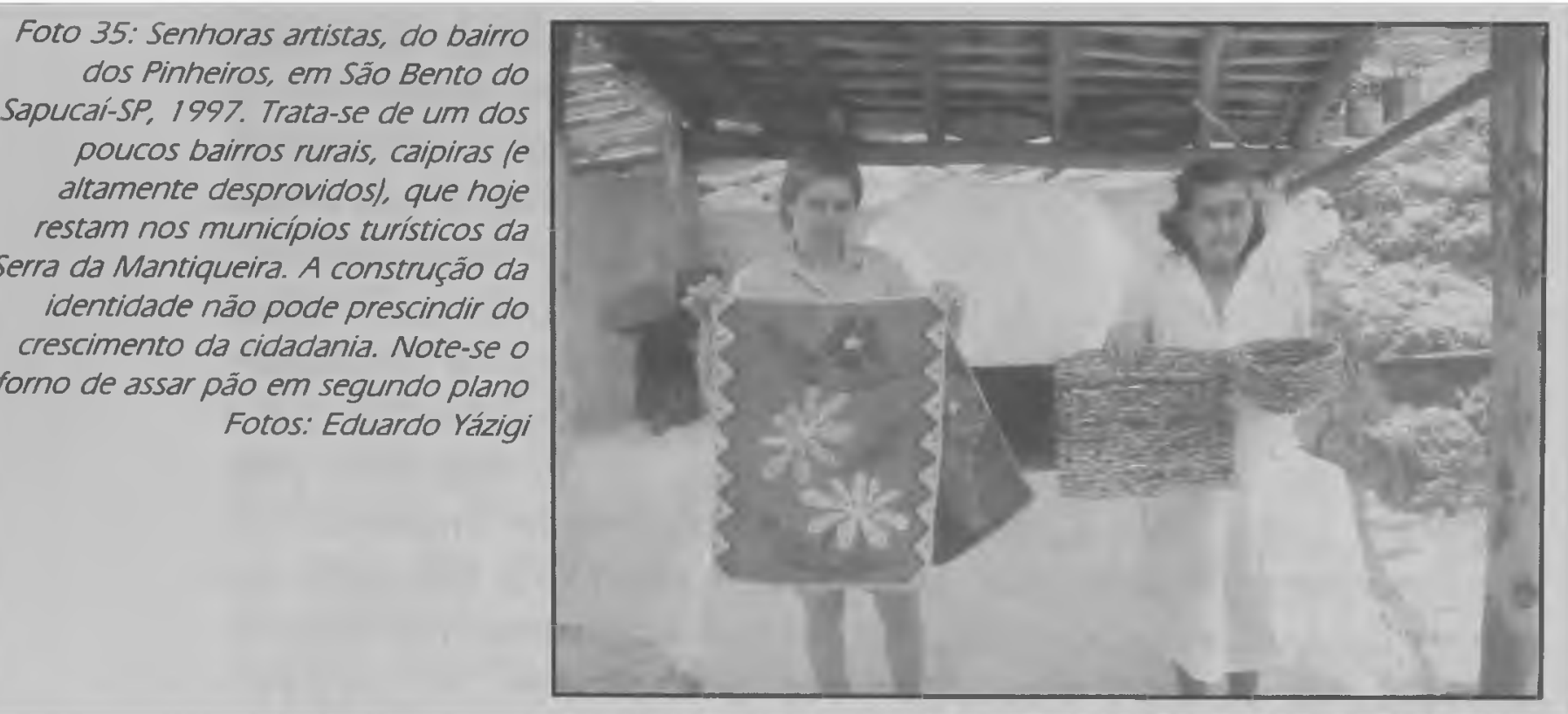

considerado ecológico, inclusive fatos negativos, já que esta disciplina estuda relações, independentemente de qualidade. Na medida em que a preservação ou reabilitação do meio natural são admitidas como diretrizes estruturais, inclusive das operações urbanísticas, tem-se algumas conseqüências de imediato.

Os estudos de impacto ambiental ainda não lograram definir com rigor científico os limites de carga para cada ecossistema, o que não deve, de modo algum, induzir à liberalização do uso e ocupação do solo. Sabese, entretanto, que os excessos têm produzido rupturas /cadeias alimentícias e por conseqüência de espécies animais e vegetais; enchentes; perda crescente de visuais paisagísticos; alterações imediatas no microclima, etc.). Daí porque a diretriz do bom senso (que outrora sempre guiou as melhores produçōes urbanísticas e mesmo arquitetônicas), de se mexer o menos possível no meio, fica inevitavelmente seguida de várias opçōes metodológicas.

Uma primeira postura, tendo em conta a primazia da geografia física na construção da identidade regional, sugere não só a rigorosa preservação de todas reservas, com os desafios socioeconômicos já aludidos, como resguardá-las com proteções adicionais à paisagem. Isto nos remete, hierarquicamente, à distribuição sábia (e técnica) de regiões de altas, médias e baixas densidades, tanto na costa como no complexo montanhoso. Daí as taxações adicionais que se imprimirão, especialmente às baixas densidades, como forma de não inviabilizar o valor na terra. E de indenização pelo custo de urbanização que provoca nos municípios. Isto é, enquanto usos de interesse social /colônias de 
férias, zonas agrícolas, clubes sociais e outras ocupações extensivas) fossem admitidos, habitações horizontais unifamiliares teriam não só de dispor de lotes imensos, como todo parcelamento ou remembramento do solo controlado com rigor espartano. Coordenei um ensaio técnico desta natureza, que pode ser encontrado na primeira versão do Plano de Uso e Ocupação da Serra do Itapeti, sob a tutela da Emplasa, nos anos 80. Do mesmo modo procurei imprimir o jogo de densidades nos termos de referência que deram origem à primeira lei de uso e ocupação do solo de Ubatuba, que acabou sendo elaborada pelo geógrafo Luís Carlos Gottsfritz: ele simplesmente imprimiu um macrozoneamento ambiental, totalmente baseado na fisiografia, ao resguardar a urbanização em planícies alveolares costeiras, nas áreas de encosta, nas de topo e escarpamento $e$, finalmente, no conjunto serrano inteiro. A partir daí atribuíram-se os usos. Em que pesem alterações na lei, parte do desenho urbano é devida a esse posicionamento técnico. É assim que um projeto de uso e ocupação do solo, pautado na manutenção do grande lote e na estratégia de uso das densidades, assim como em negociações pode se revelar como o primeiro passo para a qualificação da paisagem. Mas o imediatismo das administrações é incapaz de voltar-se para o futuro, além de negligenciar toda a questão da importância da identidade.

A idéia de zonas de alta densidade costuma assustar o público mais desavisado, cheio de deus-me-livres. Mas a realidade da urbanização miliquilométrica que se constrói ao longo de todo litoral brasileiro conduz à verticalização concentrada, como única opção de proteção da paisagem regional, fato este que pode ser compensado com projetos inteligentes. Infelizmente, os seis bilhões de habitantes do mundo, com todos reclamando um lugar ao sol, são incompatíveis com o bucolismo que todos pretendem ter à porta.

Mas uma região, apesar do próprio conceito de homogeneidade que embute, apresenta nuances, de retenção indispensável ao projeto de paisagismo. Sílvio Soares Macedo (1996, p. 159) já denunciou várias vezes o padrão de ocupação do litoral brasileiro, apontando além da poluição das águas (lençol freático, rios, lagunas, mar e áreas estuarinas), a erradicação de dunas; de matas de restinga; de assoreamento de rios, praias e estuários; de danificação dos costões; de eliminação de manguezais; de transformação da estruturas urbanas primitivas; da contaminação e destruição parcial de recifes de coral sem falar em outros pormenores ou na obstrução de visuais.

\begin{tabular}{|c|c|c|}
\hline 96 & Paisagem & São Paulo n. 11 p. $71 \quad 98$ dez. 1998 \\
\hline & $\begin{array}{l}\text { Ensaios } \\
11\end{array}$ & \\
\hline
\end{tabular}


Porquanto haja ausência de padrões arquitetônicos oficialmente admitidos, a fisiografia se apresenta como a grande diretriz, a partir da qual as diversas culturas poderiam reinterpretar a preservação. Não excluo a possibilidade de adoção de alguns padrões mínimos, mas resulta que atualmente não há uma discussão sobre a cultura regional brasileira, com níveis aceitáveis de representatividade, que tenha força suficiente em vista de uma normatização mais formal. Entremente, sou de opinião que a preservação ambiental nos moldes propostos gera princípios arquitetônicos e de paisagismo privado no caminho da construção de identidades. Por exemplo, ao optar pela ventilação cruzada em meio da floresta amazônica, em detrimento do ar condicionado, acabei por ter de definir materiais, cores e formas a serem empregados, o que acabou sugerindo modalidades de ocupação das quadras, calculadas em função de zonas de alta e baixa pressão, influindo até no local de colocação dos espelhos d'água (Yázigi, 1972). Todavia, dado o padrão não convencional deste urbanismo, o mesmo tem se limitado a condomínios privados, sendo raramente extensivo a toda urbanização, como o é em Kourou na Guiana Francesa ou em alguns pontos da África Equatorial.

Em meio ao neo-ecletismo, um estilo vem se afirmando em vários pontos do litoral brasileiro, com grande expressividade nas costas do estados de São Paulo ao Espírito Santo: a arquitetura de madeira e vidro, muitas vezes sabiamente se submetendo aos declives de terrenos. Sem cor local, mas simpática. Outras manifestaçōes esdrúxulas que vão desde um pseudo forte medieval em São Sebastião aos telhados de inclinação "para fazer a neve escorregar", em São Bento do Sapucaí e Ubatuba, são incontidas... Falar de personalidade de um lugar implica reconhecer múltiplas identidades que vão desde os aspectos físicos à captação do amplo movimento contemporâneo, gerado por migrações, populações de aposentados e minorias como as do índio ou do caiçara-caipira. É neste ponto do raciocínio que estimo impor a preponderância da fisiografia - fato aliás reforçado pelo ecologismo de nossos dias - como geradora de diretrizes e que podem, sem qualquer impedimento, ser fonte de reinterpretação de culturas, pelo menos neste momento histórico. 


\section{BIBLIOG R A F I A}

CÂNDIDO, Antonio. Parceiros do rio Bonito. São Paulo: Duas Cidades, 1979.

HILLMAN, James. Cidade \& alma. São Paulo: Nobel, 1993.

MACEDO, Sílvio Soares; PELLEGRINO, Paulo Renato Mesquita. "Do éden à cidade transformaçōes da paisagem litorânea brasileira“ In: YÁZIGI, Eduardo et al. Turismo espaço paisagem e cultura. São Paulo: Hucitec, 1996.

QUEIROZ, Maria Isaura. O campesinato brasileiro. Ensaios sobre civilização e grupos rústicos do Brasil. Petrópolis: Editora Vozes, 1973.

YÁZIGI, Eduardo. Études préliminaires en vue d'un urbanisme tropical pour l'Amazonie brésılienne. Paris: Université de Paris, 1972.

WILLEMS, Emílio. A aculturação dos alemães no Brasil. São Paulo: Cia. Editora Nacional, 1946.

\section{Paisagem}

Ambiente

Ensaios

11
São Paulo n. 11 p. 7198 dez. 1998 